University of Wyoming College of Law

Law Archive of Wyoming Scholarship

5-8-2012

\title{
A Rush to (Summary) Judgment in Franchisor Liability Cases?
}

Harvey Gelb

University of Wyoming College of Law, hgelb@uwyo.edu

Follow this and additional works at: https://scholarship.law.uwyo.edu/faculty_articles

\section{Recommended Citation}

Gelb, Harvey, "A Rush to (Summary) Judgment in Franchisor Liability Cases?" (2012). Faculty Articles. 26. https://scholarship.law.uwyo.edu/faculty_articles/26

This Article is brought to you for free and open access by the UW College of Law Faculty Scholarship at Law Archive of Wyoming Scholarship. It has been accepted for inclusion in Faculty Articles by an authorized administrator of Law Archive of Wyoming Scholarship. 


\title{
WYOMING LAW REVIEW
}

\section{A RUSH TO (SUMMARY) JUDGMENT IN FRANCHISOR LIABILITY CASES?}

\author{
Harvey Gelb* \\ TABLE OF CONTENTS
}

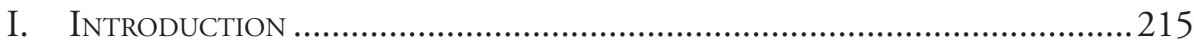

II. Respondeat Superior and Franchisor Liability ...................................217

III. Apparent Agency and Estoppel ...........................................................232

A. The Restatement (Third) of Agency and Section 267...........................234

B. Restatement Guidance.....................................................................235

C. Apparent Agency Cases Illustrating Narrow Approaches ........................2.237

D. Apparent Agency Cases Illustrating Broader Approaches........................242

IV. The Impact of the Restatement of Torts on Franchisor Liability Cases-APparent Authority ..............................................................254

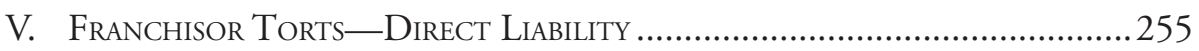

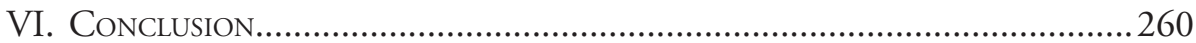

\section{INTRODUCTION}

Franchises are a common feature of the business landscape. This article explores the question of when a franchisor should be liable vicariously or directly for torts arising in a franchised enterprise. In doing so, it addresses serious and unsettled issues of tort and agency law and questions judicial fact finding in cases with summary judgments favorable to franchisors.

* Professor and Kepler Chair in Law and Leadership Emeritus, University of Wyoming College of Law; B.A. 1957, Harvard College; J.D. 1960, Harvard Law School. The author appreciates the generous support from the Kepler Chair in Law and Leadership Fund in sponsoring summer grants and student assistants for this article. The author thanks Kala Geanetta, Stephanie Holguin, Kimberly Ingelhart, Richard McKinnon, and Shannon Rogers for their outstanding work as student research assistants. The author also thanks his son, Attorney James M. Gelb, for once again contributing excellent and creative editing assistance. 
The fundamental question of who is responsible for tort injuries as a matter of law and as a matter of fact is recurrent and often difficult. There is, of course, the general legal principle that the person who commits a tort should be responsible to the victim for damages. Beyond that are principles of respondeat superior that establish employer responsibility for employee torts committed within the scope of employment. There is sometimes responsibility for persons even when they engage non-employees to perform certain tasks. ${ }^{1}$ In addition, to encourage investment, the law provides limited liability for persons who pursue business in prescribed forms like corporations, limited liability companies or limited liability partnerships. ${ }^{2}$

The ways in which persons organize to further their enterprises are often complex. They may use several entities and types of entities. The enterprise may have parents, subsidiaries and other affiliates. They may use non-employee agents, employees and independent contractors. They may also utilize franchisees. As a general proposition, one can safely assume that franchisors wish to preserve limited liability for themselves and various components of their business and that they prefer to be shielded from franchisee torts. It is very doubtful that customers of franchised establishments give thought to such matters and if they did there would be technical, informational, and time constraints which would often render futile their search for "who am I really buying this sandwich from" or "who may be liable if I am injured eating it." Quite likely, it is often the magnetic pull of a well-known and well advertised franchise name which has drawn customers to an establishment.

In the context of this article, vicarious liability involves franchisor responsibility for tort liability of the franchisee and direct liability involves franchisor responsibility for its own torts. Although the term franchising may be used to label a variety of relationships, the following description set forth by the Wisconsin Supreme Court in Kerl v. Rasmussen is adequate for this article:

A franchise is a business format typically characterized by the franchisee's operation of an independent business pursuant to a license to use the franchisor's trademark or trade name. A franchise is ordinarily operated in accordance with a detailed franchise or license agreement designed to protect the integrity of the trademark by setting uniform quality, marketing, and operational standards applicable to the franchise. ${ }^{3}$

1 See discussion infra Section IV (discussing the impact of the Restatement of Torts on vicarious liability).

2 This form of limited liability, in the case of non-publicly owned entities, is subject to challenge under "piercing the veil" doctrines. See generally Harvey Gelb, Limited Liability Policy and Veil Piercing, 9 Wyo. L. Rev. 551 (2009).

${ }^{3}$ Kerl v. Rasmussen, 682 N.W.2d 328, 331 (Wis. 2004). 
The degree and scope of franchisee independence from the franchisor as well as a customer's perception of whose business is being patronized often present key legal and factual questions when dealing with summary judgment motions regarding vicarious liability claims.

Not surprisingly, courts often look to agency law for analogy and guidance in determining franchisor vicarious liability. Agency doctrines have long dealt with the principles and policies of vicarious liability of employers (masters) under the doctrine of respondeat superior for the torts of employees (servants) committed within the scope of their employment as well as for such liability arising from claims of apparent agency or estoppel.

The following three sections of this article discuss franchisor vicarious liability for franchisee torts from several perspectives. Section II focuses on the use of principles of respondeat superior. Section III deals with apparent agency and estoppel. Section IV considers the impact of the Restatement of Torts on vicarious liability. Additionally, Section V deals with the direct liability of the franchisor for its own torts related to the franchised business.

At the outset, it is important to note a factor complicating the consideration of agency principles, the Restatement (Third) of the Law of Agency. In 2006, the influential American Law Institute adopted the Restatement (Third) of the Law of Agency with changes in terminology and otherwise from its predecessor. In reading cases and other materials involving agency principles, awareness of these changes and considerations of the complications caused may prove important.

\section{Respondeat Superior and Franchisor Liability}

Under the well-established principle of respondeat superior, "[a]n employer is subject to liability for torts committed by employees while acting within the scope of their employment." ${ }^{4}$ The Restatement (Third) of Agency defines the term "employee" as "an agent whose principal controls or has the right to control the manner and means of the agent's performance of work." Obviously, this definition requires that one be an "agent" as a prerequisite to being classified as an "employee." As defined by the Restatement (Third) of Agency, "[a]gency is the fiduciary relationship that arises when one person (a 'principal') manifests assent to another person (an 'agent') that the agent shall act on the principal's behalf and subject to the principal's control, and the agent manifests assent or otherwise consents so to act." A plain reading of these Restatement sections demonstrates that the degree of control over the performance of work distinguishes a nonemployee from an employee agent.

\footnotetext{
${ }^{4}$ Restatement (Third) of Agency $\$ 2.04$ (2006). See also id. $\$ 7.07(1)$.

${ }^{5}$ Restatement (Third) of Agency $\$ 7.07$ (3) (a) (2006).

${ }^{6}$ Id. $\$ 1.01$.
} 
At times, the franchise label may be applied to relationships that are so constituted that the franchisor really is an employer and the franchisee an employee. In such cases, the vicarious liability of the franchisor for the torts of the franchisee can be resolved under the traditional agency law doctrine of respondeat superior. However, many franchise relationships do not meet the technical requirements that would establish an employer-employee relationship and are not truly governed as to vicarious liability by the literal terms of respondeat superior. For example, under the Restatement (Third) of Agency definitions cited above, an employee must be an agent, and agency involves a fiduciary relationship between the agent and the principal in which the former is to act on behalf of the latter. ${ }^{7}$ It is unlikely that the typical relationship of a franchisee to a franchisor involves a fiduciary duty from one to the other or that the "on behalf of" element is present.

Furthermore, when analyzing vicarious liability agency doctrines, one must be mindful of variations in terminology. While under the latest Restatement (Third) of Agency, the principal-agent relationship is also considered and labeled as an employer-employee relationship when the principal's control over the agent attains the prescribed higher level of control over the work, ${ }^{8}$ the previous label for such a relationship was master-servant. ' Use of the terms "employer" and "employee" represents a deliberate effort in the Restatement (Third) of Agency to substitute those words for outdated master-servant terminology. ${ }^{10}$ Vicarious liability principles are applicable to what this Restatement (Third) of Agency calls employer-employee relationships.

Along similar lines, it should be noted that courts have not always been careful in using terminology in traditional Restatement ways. Occasionally courts may use the term "agent" when it would be more appropriate to use "servant" or "employee." 11

Readers of cases and other materials need to be conscious of possible variations in terminology. Some courts analyze the vicarious liability of franchisors as if ordinary agency rules govern without mentioning that the value of such rules often exists only because of the analogous light they may shed. Others recognize the uniqueness of many franchise relationships but consciously borrow from respondeat superior vicarious liability concepts and particularly the control factor inherent in such concepts in deciding franchisor liability issues.

\footnotetext{
${ }^{7} \mathrm{Id}$.

8 See id. $\$ 7.07(1)$.

9 See Restatement (Second) of Agency $\$ 2$ (1958).

10 Restatement (Third) of Agency intro. (2006).

11 See generally Billops v. Magness Constr. Co., 391 A.2d 196 (Del. 1978).
} 
For example, in Miller v. McDonald's Corp., a case involving a claim against a franchisor arising from an injury incurred from biting into a sandwich, the court spoke in terms of an actual agency relationship, stating, "[t]he kind of actual agency relationship that would make defendant vicariously liable for 3K's negligence requires that defendant have the right to control the method by which $3 \mathrm{~K}$ performed its obligations under the Agreement. The common context for that test is a normal master-servant (or employer-employee) relationship." 12 Significantly, the court noted that a relationship between two business entities is not precisely an employment relationship but still applied the right to control test in the franchisee context. ${ }^{13}$

Also the Delaware Supreme Court, in Billops v. Magness Construction Co., quoted agency terminology but without using the narrower and more traditional servant-agent (or employee-agent) terminology involved in respondeat superior vicarious liability, saying "[i]f, in practical effect, the franchise agreement goes beyond the stage of setting standards, and allocates to the franchisor the right to exercise control over the daily operations of the franchise, an agency relationship exists. ${ }^{14}$

On the other hand, there are courts which have explicitly stated that suits against franchisors require a different approach than employer vicarious liability suits. ${ }^{15}$ In two important cases, the highest courts of both Wisconsin and Maine referred to franchisor vicarious liability cases as being of first impression but drew from agency law control principles in resolving, albeit differently, what the law should be. ${ }^{16}$

In Murphy v. Holiday Inns, Inc., the plaintiff alleged that, while a guest at a Holiday Inn motel, she slipped and fell on an area of walkway where water draining from an air conditioner had been allowed to accumulate. ${ }^{17}$ She sought damages from the defendant, Holiday Inns, Inc. (Holiday), arguing that "[Holiday], its agents and employees ... carelessly, recklessly, and negligently maintained the premises of the motel." ${ }^{\prime 18}$ Holiday filed a motion for summary judgment, arguing its only relationship with the operator of the motel was a license agreement permitting the operator to use the name "Holiday Inns."19 The trial court granted

12945 P.2d 1107, 1110 (Or. Ct. App. 1997).

${ }^{13} \mathrm{Id}$.

14391 A.2d at $197-98$.

15 See Rainey v. Langen, 998 A.2d 342 (Me. 2010); Kerl v. Rasmussen, 682 N.W.2d 328 (Wis. 2004).

${ }^{16}$ Rainey, 998 A.2d at 346-47; Kerl, 682 N.W.2d at 337.

17219 S.E.2d 874, 875 (Va. 1975).

${ }^{18} \mathrm{Id}$.

${ }^{19}$ Id. 
Holiday's motion, finding that Holiday did not own the motel premises and that no principal-agent or master-servant relationship existed between Holiday and the licensee corporation, Betsy-Len Motor Corporation (Betsy-Len). ${ }^{20}$

On appeal, the Supreme Court of Virginia considered whether Holiday and Betsy-Len had an "agency relationship." ${ }^{21}$ The court stated, "[ $[\mathrm{t}$ he fact that an agreement is a franchise contract does not insulate contracting parties from an agency relationship," 22 and, "[i]f a franchise contract 'so regulates the activities of the franchisee' as to vest the franchisor with control within the definition of agency, the agency relationship arises even though the parties expressly deny it." ${ }^{23}$ The court then examined the regulatory provisions in the franchise agreement between Holiday and Betsy-Len:

[T] he purpose of those provisions was to achieve system-wide standardization of business identity, uniformity of commercial service, and optimum public good will . . . The regulatory provisions did not give [Holiday] control over the day-to-day operation of Betsy-Len's motel. While [Holiday] was empowered to regulate the architectural style of the buildings and the type and style of furnishings and equipment, [Holiday] was given no power to control daily maintenance of the premises. [Holiday] was given no power to control Betsy-Len's current business expenditures, fix customer rates, or demand a share of the profits. [Holiday] was given no power to hire or fire Betsy-Len's employees, determine employee wages or working conditions, set standards for employee skills or productivity, supervise employee work routine, or discipline employees for nonfeasance or misfeasance. All such powers and other management controls and responsibilities customarily exercised by an owner and operator of an on-going business were retained by Betsy-Len. ${ }^{24}$

Based on this analysis, the court held that the franchise agreement did not give Holiday "control or right to control the method or details of doing the work" and that "no principal-agent or masterservant [sic] relationship was created." 25
20 See id.
${ }^{21}$ See id. at 877.
${ }^{22} \mathrm{Id}$.
${ }^{23} \mathrm{Id}$.
${ }^{24} I d$. at 878 .
${ }^{25} \mathrm{Id}$. at 877 . 
The court's reference to "control" illustrates the terminological confusion referenced earlier ${ }^{26}$ Though the court ostensibly considered whether the parties had an "agency relationship" 27 and ultimately held "that the regulatory provisions of the franchise contract did not constitute control within the definition of agency," 28 the court's analysis (quoted above) would have been better directed to the question of control sufficient to establish a master-servant relationship. The court may have been uneasy about its use of terminology, accompanying its statement that "no principal-agent or masterservant [sic] relationship was created" with a footnote in which it stated: "Because [Holiday] had no such control or right to control, the distinction between a principal-agent and a master-servant relationship is not relevant here." ${ }^{29}$ This footnote hardly clarifies the matter. The court concluded that the regulatory provisions of the franchise contract did not constitute control within the definition of agency thus evidencing the same kind of terminological confusion earlier mentioned. ${ }^{30}$

In a leading Wisconsin case, Kerl v. Rasmussen, the Wisconsin Supreme Court upheld a summary judgment ruling favoring the franchisor in a franchisor vicarious liability suit. ${ }^{31}$ In Kerl, a work-release inmate employed at an Arby's restaurant operated by Dennis Rasmussen, Inc. (DRI) left work without permission, shot two persons, then killed himself. ${ }^{32}$ The plaintiffs, including the guardian of the first victim and the estate of the second, sued Arby's and DRI on several grounds and argued, among other things, that Arby's was vicariously liable for DRI's negligent supervision of its employee. ${ }^{33}$ The trial court granted summary judgment in favor of Arby's on the ground there was no basis for vicarious liability. ${ }^{34}$ On appeal, the Wisconsin Supreme Court affirmed the summary judgment. ${ }^{35}$

Kerl contains a detailed discussion of franchisor vicarious liability for franchisee torts. ${ }^{36}$ Although the court did not purport to decide the matter as an agency law issue, it analyzed agency law vicarious liability principles in arriving at its decision. ${ }^{37}$ The lone issue before the court on appeal was that of Arby's vicarious

\footnotetext{
26 See supra text accompanying notes 8-14.

${ }^{27}$ Murphy, 219 S.E.2d at 876.

${ }^{28} \mathrm{Id}$. at 878 .

${ }^{29} I d$. at $877 \&$ n. 2 .

${ }^{30} \mathrm{Id}$. at 878 .

${ }^{31} 682$ N.W.2d 328, 331 (Wis. 2004).

${ }^{32} \mathrm{Id}$.

${ }^{33} I d$. at 331-33.

${ }^{34} I d$. at 331 .

${ }^{35} \mathrm{Id}$. at 332.

36 See id. at 337-41.

37 See id.
} 
liability as franchisor for DRI's alleged negligent supervision of its employees. ${ }^{38}$ Considering the issue as one of first impression in Wisconsin, the intermediate court of appeals had "surveyed case law from other jurisdictions and concluded that the prevailing standard for franchisor vicarious liability focuses on whether the franchisor controls the 'specific instrumentality' which allegedly caused the harm, or whether the franchisor has a right of control over the alleged negligent activity." ${ }^{39}$ The court explained that " $[\mathrm{u}]$ nder the doctrine of respondeat superior, a master is subject to liability for the tortious acts of his or her servant" ${ }^{\prime 40}$ and that " $[t]$ he master/servant relationship is a species of agency [and] that all servants are agents." ${ }^{\prime 11}$ The Wisconsin Supreme Court agreed, holding "that a franchisor may be held vicariously liable for the tortious conduct of its franchisee only if the franchisor has control or a right of control over the daily operation of the specific aspect of the franchisee's business that is alleged to have caused the harm." ${ }^{42}$ Applying this rule, the court concluded the trial court had properly granted summary judgment in favor of Arby's because the license agreement did not give Arby's the right of control over DRI's supervision of its employees even though it "imposed many quality and operational standards on the franchise." ${ }^{43}$

The Wisconsin Supreme Court's decision in Kerl, and the arguments it stated in favor of its decision, indicate the court was determined to construe franchisor vicarious liability for franchisee torts in a restrictive manner, and its approach leaves summary judgment as a formidable weapon for franchisor defendants. ${ }^{44} \mathrm{To}$ begin with, the predisposition of the court in favor of summary judgment for the franchisor is plainly illustrated by this statement:

If the operational standards included in the typical franchise agreement for the protection of the franchisor's trademark were broadly construed as capable of meeting the "control or right to control" test that is generally used to determine respondeat superior liability, then franchisors would almost always be exposed to vicarious liability for the torts of their franchisees. We see no justification for such a broad rule of franchisor vicarious liability. If vicarious liability is to be imposed against franchisors, a more precisely focused test is required. ${ }^{45}$

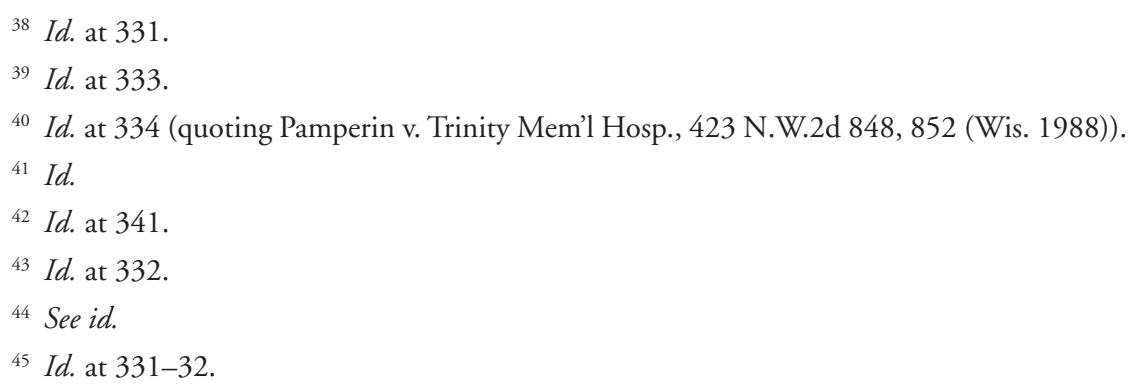


Secondly, without reference to any survey or study the court arrived at the somewhat astounding conclusion "that the marketing, quality, and operational standards commonly found in franchise agreements are insufficient to establish the close supervisory control or right of control necessary to demonstrate the existence of a master/servant relationship for all purposes or as a general matter." ${ }^{36}$ The court's willingness to generalize about franchise agreements in order to create a restrictive vicarious liability approach in favor of franchisors is inappropriately speculative. Courts should examine the terms of such agreements on a case by case basis rather than trumpeting a purported commonly found standard that, unfortunately, may be echoed by other courts who repeat it as a truth revealed by a respected sister court. Nor should the temptation to walk the short and easy road to summary judgment, in preference to the more grueling path of a trial, be allowed to engender conclusory presumptions against plaintiffs.

Additionally, the Kerl opinion did not deal with the realities of the control relationship between a franchisor and franchisee. It may be that this question was not raised..$^{47}$ Evidence of such realities may demonstrate a level of control by the franchisor far greater than the documents indicate. De facto control may arise in some situations from franchisee reluctance to defy franchisor recommendations. Nor should courts casually toss aside franchisor powers of inspection or termination as irrelevant to control determinations. Indeed, in some cases realistic control determinations may best be made after trial testimony, however inconvenient that may seem to proponents of summary judgments. The question of the presence of de facto control of the franchisor, even where it does not arise from franchise documents, would preclude summary judgments in some cases. ${ }^{48}$ Additionally the question of franchisor liability for its behavior or exercise of power may raise issues of its direct liability for injuries. ${ }^{49}$

The Kerl case raised a number of policy considerations in dealing with franchisor vicarious liability that shed light on its ruling:

1. There is a modern consensus justifying vicarious liability "on common law policy grounds as a device for spreading risk and encouraging safety and the exercise of due care by employees/servants." ${ }^{\text {50 }}$ The court

\footnotetext{
${ }^{46} I d$. at 332.
}

${ }^{47}$ See id.

48 See Hoover v. Sun Oil Co., 212 A.2d 214, 216 (Del. Super. Ct. 1965) ("However, the lease contract and dealer's agreement fail to establish any relationship other than landlord-tenant, and independent contractor. Nor is there anything in the conduct of the individuals which is inconsistent with that relationship so as to indicate that the contracts were mere subterfuge or sham.").

${ }^{49}$ See discussion infra Section V.

${ }^{50} \mathrm{Kerl}, 682 \mathrm{~N} . \mathrm{W} .2 \mathrm{~d}$ at 336 
explained that exposure to vicarious liability creates an incentive for masters to properly control the conduct of their servants so as to ensure that they will exercise due care in carrying out the master's business; that employees are less responsive to the threat of tort liability than employers because the former usually are less able to satisfy judgments for damages; and that employers are usually better able financially to absorb the costs of supervision and safety measures or to insure against the risk. ${ }^{51}$

2. Admitting the rationale for vicarious liability has expanded and its application has become more diverse, the court still stated "only a 'master' who has the requisite degree of control or right of control over the physical conduct of a servant in the performance of the master's business will be held vicariously liable." ${ }^{52}$ Absent such a control element, the court felt the opportunity and incentive to promote safety and the exercise of due care are not present and imposing liability without fault would be difficult to justify on such grounds..$^{53}$

3. Positing that a franchisor's control does not extend to "routine, daily supervision and management" but is limited to "contractual quality and operational requirements necessary to the integrity of the franchisor's trade or service mark," the court stated that "[t]he perceived fairness of requiring a principal who closely controls the physical conduct of an agent to answer for the harm caused by the agent is diminished in this context." ${ }^{14}$ The court also stated that encouraging safety and the exercise of due care has less strength as a justification for imposing no fault liability on a franchisor. ${ }^{55}$ The court concluded that the clear trend in the case law of other jurisdictions is that quality and operational standards and inspection rights contained in a franchise agreement do not establish the requisite control or right of control for vicarious liability as a general matter for all purposes. ${ }^{56}$

4. The court identified a variety of franchising forms including product franchises, business format franchises, and certain kinds of dealerships, and specifically pointed to the form of franchising

\footnotetext{
${ }^{51} I d$.

$52 \mathrm{Id}$.

${ }^{53} \mathrm{Id}$. at $336-37$.

${ }^{4} \mathrm{Id}$. at 338.

${ }^{55} \mathrm{Id}$.

${ }^{56} \mathrm{Id}$.
} 
before it, under which there is a sale of a product or service under the franchisor's trademark pursuant to specified quality, marketing and operational standards. ${ }^{57}$ The court noted among other things that "[ $t]$ he franchise arrangement enables the franchisor to reach new, farflung markets without having to directly manage a vast network of individual outlets." ${ }^{58}$ Perhaps the court here was implicitly displaying approval of franchising as a way of doing business and its reluctance to encumber franchisors with responsibility for accidents or their prevention.

5. The court stated that, generally, the justifications for vicarious liability are lost in the franchising context and the control or right to control test is not easily transferable to the franchise relationship. ${ }^{59}$ Referring to the detailed requirements of franchise agreements with respect to franchisee operations, the court said, "existence of these contractual requirements does not mean franchisors have a role in managing the day-to-day operations of their franchisees." ${ }^{60}$ Indeed, the court unconvincingly stretched the point to say "imposition of quality and operational requirements by contract suggests that the franchisor does not intervene in the daily operation and management of the independent business of the franchisee." ${ }^{11}$

6. Alluding to the detailed quality and operational standards and inspection rights in a franchise agreement as integral to the protection of the franchisor's trade or service mark under the Lanham Act, the court said the purpose of the Act is to ensure the integrity of registered trademarks and not to create a federal law of agency which automatically saddles the licensor with responsibilities under state law of a principal. ${ }^{62}$

${ }^{57}$ Id. at 337.

$58 \mathrm{Id}$.

59 Id.

${ }^{60} \mathrm{Id}$. at 338 .

${ }^{61} \mathrm{Id}$.

${ }^{62}$ Id. (citing Oberlin v. Marlin Am. Corp., 596 F.2d 1322, 1327 (7th Cir. 1979)). The federal Lanham Act, title 15, chapter 22 of the United States Code, codified much of traditional trademark infringement law and "broadly prohibits uses of trademarks, trade names, and trade dress that are likely to cause confusion about the source of a product or service.” 87 C.J.S. Trademarks, Etc. $\$ 81$ (2012). In Oberlin, the Seventh Circuit observed that " $[\mathrm{t}]$ he Lanham Act requires supervision of trademark licensees at the expense of abandonment of the trademark. The licensor must control the operations of its licensees to ensure that the trademark is not used to deceive the public as to the quality of the goods or services bearing the name." 596 F.2d at 1327 . See also 15 U.S.C. $\$ 1055$ (2012) ("Where a registered mark . . . is or may be used legitimately by related companies, ... such use shall not affect the validity of such mark or of its registration, provided such mark is not used in such manner as to deceive the public."). 
The policy analysis of the Kerl court is open, at the least, to the following challenges:

1. The Kerl court's use of sweeping generalizations about franchisors' lack of control may undermine careful case-by-case fact finding about control, thereby eliminating the opportunity to advance policies of safety and care that trigger respondeat superior liability. Indeed franchisors, even if not technically employers, may be in a better position than some employers in the same type of business to know about the risks and perils of the business through their wide ranging experience and education acquired both independently and through their franchised locations. Franchisors with such informational assets should share them with franchisees and advance goals of safety and care.

2. It will often behoove franchisors, as a matter of good business policy and not just to avoid liability, to require franchisees to promote safety in their practices and environment. In addition, inspection powers and activity enable franchisors to identify and hopefully deal with safety concerns.

3. Franchisor responsibility for franchisee torts may assure a realistic assessment of insurance needs and thus help to provide injured persons with appropriate recoveries.

4. Reference by the court to Lanham Act requirements as some kind of excuse or reason to protect franchisors from vicarious tort liability resulting from franchisee behavior is inappropriate. Persons in business may be subject to a variety of regulations causing the level of control they exercise over employees or others to increase. Why should Lanham Act requirements be construed in some perverse way to undermine vicarious liability principles? ${ }^{63}$

In Kerl the court struck a serious but unconvincing blow against plaintiffs seeking fact finding through trials, both by its conclusory generalization regarding standardized provisions of franchise agreements and its preconception that franchisor liability should be narrowly circumscribed.$^{64}$ The view of the court about

${ }^{63}$ See supra note 62 and accompanying text.

${ }^{64} \mathrm{Kerl}, 682 \mathrm{~N} . \mathrm{W} .2 \mathrm{~d}$ at 341 . The court said:

Consistent with the majority approach in other jurisdictions, we conclude that the standardized provisions commonly included in franchise agreements specifying uniform quality, marketing, and operational requirements and a right of inspection do not establish a franchisor's control or right to control the daily operations of the 
"standardized provisions commonly included" has been questioned. However, the practical impact of the court's holding, seemingly concerned with divided operations in a franchise business, is harder to assess. In applying its principles to the case before it, the court did review documents and stated that the license agreement contained many general controls on the operation of the restaurant, and required the franchisee to operate the business strictly in conformity with the manual provided by Arby's. The court also stated the provisions in the agreement are consistent with quality and operational standards commonly contained in franchise agreements to achieve marketing uniformity in products and to protect the franchisor's trademark, but insufficient to establish a master/servant relationship or to establish that Arby's controlled or had a right to control the hiring and supervision of employees, which is the aspect of the business alleged to have caused the plaintiff's harm. ${ }^{65}$ The court noted the agreement and manual contained provisions for the franchisee to properly supervise qualified personnel for the efficient operation of the business and that the manual provided guidelines for hiring, training, and supervising employees ${ }^{66}$ The court also noted that DRI had sole control over the hiring and supervision of employees and Arby's could not step in and take over management of employees. ${ }^{67}$ Importantly, the court stated that Arby's right to terminate their relationship because of an uncured violation of the agreement was not equivalent to a right to control daily operations of the restaurant or to manage the workforce and that there was no genuine issue of material fact as to whether the franchisee was a servant for purposes of the respondeat superior claim which it clearly was not. ${ }^{68}$ The court held Arby's could not be vicariously liable for the franchisee's negligent supervision of the employee whose actions directly caused the damages. ${ }^{69}$

However, Kerl, along with a number of other franchise cases, in their preoccupation with franchise documents, do not get to the heart of the matter: What is the reality in fact of the franchisor's control? Furthermore, are there not good policy reasons, considered earlier, to encourage a franchisor to use its power to promote safety and care? ${ }^{70}$ Moreover, it is difficult to assess the true impact of

franchisee sufficient to give rise to vicarious liability for all purposes or as a general matter. We hold that a franchisor may be held vicariously liable for the tortious conduct of its franchisee only if the franchisor has control or a right of control over the daily operation of the specific aspect of the franchisee's business that is alleged to have caused the harm.

Id.

${ }^{65} \mathrm{Id}$. at 342.

${ }^{66} \mathrm{Id}$.

${ }^{67} \mathrm{Id}$.

${ }^{68} \mathrm{Id}$.

${ }^{69} \mathrm{Id}$.

${ }^{70}$ See supra text accompanying notes 62-63 (discussing policy reasons). 
a franchisor's right to terminate a franchise without understanding the realities of the relationship between franchisor and franchisee.

A properly analyzed vicarious liability case should take into account not only the requirements of documents signed by the parties but also their de facto relationship and their interpretation of, and actual practices under, those documents. Parties should not be able to hide the realities of control behind the words of documents. In addition, the impact of suggestions by the franchisor on the franchisee's conduct might be an issue best resolved by the ultimate fact finder, such as a jury, and not by summary judgment. As a policy matter, why should a franchisor with real power and expertise not be encouraged to try to prevent torts that might result from the behavior of the employees of the franchisee?

In a 2010 decision, the Maine Supreme Court approved a partial summary judgment in favor of Domino's Pizza, LLC (Domino's) against a claim of vicarious liability stemming from injuries sustained by one of the plaintiffs who, while riding his motorcycle, was seriously hurt in a collision with a vehicle driven by an employee of a Domino's franchisee. ${ }^{71}$ The court, recognizing the case of franchisor liability as one of first impression in Maine, looked particularly to the "right to control" test used to determine employer/employee relationships under agency law, and saw such principles as applying with equal force in the franchisor/ franchisee context. ${ }^{72}$

The court pointed to two paths taken by other courts in determining franchisor vicarious liability: application of the traditional "right to control" test focusing on a franchisor's control over a franchisee's performance of its day-today operations; and an instrumentality rule, as in the Kerl case, holding that the franchisor may be subject to vicarious liability for the tortious conduct of its franchisee only if the franchisor had control or a right of control over the daily operation of the specific aspect of the franchisee's business that is alleged to have caused the harm. ${ }^{73}$

The Maine court concluded that the traditional approach struck an appropriate balance and declined to adopt the instrumentality rule, asserting that " $[\mathrm{t}]$ he traditional test allows a franchisor to regulate the uniformity and the standardization of products and services without risking the imposition of vicarious liability." ${ }^{74}$ As in $\mathrm{Kerl}$, the court referred to Lanham Act considerations to the effect that, "the duty [imposed by the Lanham Act] does not give a licensor

\footnotetext{
71 Rainey v. Langen, 998 A.2d 342, 344 (Me. 2010).

72 Id. at 346-47.

$73 \mathrm{Id}$. at 348-49.

${ }^{74}$ Id. at 349.
} 
control over the day-to-day operations of a licensee beyond that necessary to ensure uniform quality of the product or service in question." 75 The court further said, "trademark license agreements do not in and of themselves create an agency relationship," but that "[i]f a franchisor takes further measures to reserve control over a franchisee's performance of its day-to-day operations, . . . the franchisor is no longer merely protecting its mark, and imposing vicarious liability may be appropriate. ${ }^{.76}$

The Maine court reviewed documents applicable in the franchise relationship at issue and notwithstanding Domino's having the right to conduct inspections and terminate the franchise relationship, notwithstanding a number of provisions in the franchise agreement and guide dealing with delivery of customer orders and safety of delivery drivers and vehicles, and notwithstanding the requirement "that franchisees 'strictly comply with all laws, regulations, and rules of the road and due care and caution in the operation of delivery vehicles,"'77 concluded that the controls contained/provided for in the documents fell short of control over the performance of the franchisee's day-to-day operations. ${ }^{78}$ In the concluding paragraph of the opinion, the court, basing its determination on the agreement and guide, stated that the franchisor did not retain sufficient control over the franchisee to subject itself to vicarious liability. ${ }^{79}$ Therefore, the court held the partial summary judgment was appropriate. ${ }^{80}$

Unfortunately, the court appears to have adopted a bias in its control analysis favorable to franchisors by reference to the Lanham Act, which places an affirmative duty upon a licensor of a registered trademark to take reasonable measures to detect and prevent misleading uses of the mark by its licensees. ${ }^{81}$ The court stated that to avoid noncompliance with the Lanham Act there must be adequate licensor control over the use of its mark. ${ }^{82}$ The court's view is that "the control mandated by the Lanham Act was not intended to 'saddle [a] licensor with the responsibilities under state law of a principal for his agent" and that "it is necessary to evaluate the franchise relationship in light of the franchisor's duty to police its trademark. ${ }^{33}$ Evidently, in support of its position, the court refers to a

${ }^{75}$ Id. (quoting Oberlin v. Marlin Am. Corp., 596 F.2d 1322, 1327 (7th Cir. 1979)).

${ }^{76}$ Id. (quoting L.A. Gear, Inc. v. E.S. Originals, Inc., 859 F. Supp. 1294, 1299 (C.D. Cal. 1994)) (other citation omitted).

77 Id. at 345 .

$78 \mathrm{Id}$.

79 Id. at $350-51$.

${ }^{80} \mathrm{Id}$.

81 See supra note 62 and accompanying text.

82 Rainey, 998 A.2d at 348.

${ }^{83}$ Id. (quoting Oberlin v. Marlin Am. Corp., 596 F.2d 1322, 1327 (7th Cir. 1979)). 
commentator noting "that extending vicarious liability could improperly penalize a franchisor for exercising the degree of control necessary to protect the integrity of its trademark." ${ }^{84}$ This attitude of immunizing control required by the Lanham Act from being a ground for imposing responsibility for torts due to control exercised or possessed by a franchisor is inappropriate and colors the views of the court in a manner favorable to the franchisor without regard to the purposes of tort law..$^{85}$

In the final analysis, the Maine Supreme Court's decision in Rainey reflects many of the same analytical problems that were present in $\operatorname{Kerl}$ (discussed above). ${ }^{86}$ One obvious example is the Rainey court's adoption of the Kerl court's Lanham Act argument, a questionable "follow the leader" approach.

More significantly, as in Kerl, the court in Rainey did not delve into the question of whether the franchisor enjoyed or engaged in a reality of control that was not evident from the franchise documents. As in Kerl, this may have been because the plaintiffs did not raise the issue.

Would courts reject such an inquiry if evidence were properly presented? Neither Rainey nor Kerl answers this question. In Allen v. Choice Hotels International, the Mississippi Court of Appeals seemed willing to include de facto control within the scope of its inquiry, but pointed to the lack of sworn testimony from plaintiffs challenging that of the franchisor on the matter. ${ }^{87}$ Unfortunately, the Allen court also cited Kerl for the proposition that "the quality and operational standards and inspection rights contained in a franchise agreement do not establish a franchisor's control or right to control over the franchise sufficient to ground a claim for vicarious liability," sadly illustrating how an inappropriate but seductive view can become embedded in judicial repetitions as if it were based on some established truths. ${ }^{88}$

In addition, the Allen court's reliance on the franchisor's failure to be more forthcoming in furnishing safety standards to the franchisee as a point against franchisor liability is troubling. ${ }^{89}$ Surely, those franchisors with much

${ }^{84}$ Id.
${ }^{85}$ See supra notes 62-63 and accompanying text.
${ }^{86}$ See supra notes $50-61$ and accompanying text.
${ }^{87} 942$ So. 2 d 817,825 (Miss. Ct. App. 2006).
${ }^{88}$ Id. at 823 .
${ }^{89}$ Id. The Allen action stemmed from the death of a man and injury to his wife resulting from a struggle with robbers who had entered their hotel room. Id. The case against the franchisor claimed that it failed to provide reasonable security to protect hotel guests. Id. The court referred to some of Choice's requirements about motel doors involving their width, their viewer, deadbolt lock, and security bars but said: 
greater experience and information in a particular type of business should not be discouraged from imposing safety measures in order to avoid liability based on control.

In Miller v. McDonald's Corp., a restaurant patron sought damages from defendant McDonald's Corporation for injuries suffered from biting into a heartshaped sapphire stone while eating a Big Mac sandwich..$^{90}$ The trial court granted summary judgment to defendant on the ground that the restaurant was owned and operated by a franchisee and not the defendant franchisor. ${ }^{91}$

On appeal, the Oregon Court of Appeals recognized that even though the relationship between the franchisor and the franchisee business entities was not precisely an employment relationship, it "in common with most if not all other courts that have considered the issue, has applied the right to control test for vicarious liability in that context as well." "92 The Oregon Court of Appeals adopted a Delaware Supreme Court test: ${ }^{93}$ "If, in practical effect, the franchise agreement goes beyond the stage of setting standards, and allocates to the franchisor the right to exercise control over the daily operations of the franchise, an agency relationship exists." ${ }^{94}$

Referring to the franchisee as " $3 \mathrm{~K}$ " in the following passage, the Oregon court explained that a jury could find the franchisor retained sufficient control over the franchisee's daily operations that an actual agency relationship existed:

[T] he Agreement did not simply set standards that $3 \mathrm{~K}$ had to meet. Rather, it required $3 \mathrm{~K}$ to use the precise methods that defendant established, both in the Agreement and in the detailed manuals that the Agreement incorporated. Those methods included the ways in which $3 \mathrm{~K}$ was to handle and prepare food. Defendant enforced the use of those methods by regularly sending

We are not persuaded that these requirements show enough control to shift responsibility for safety to Choice. We note again that it is not only results that a franchisor must control, but also the means to those ends. These few requirements regarding hotel doors do not show that Choice had the right to control both the means and the ends of security at the Comfort Inn.

Id. at 822 .

90945 P.2d 1107, 1108 (Or. Ct. App. 1997).

${ }^{91} \mathrm{Id}$. (en banc)).

${ }^{92}$ Id. at 1110 (citing Peeples v. Kawasaki Heavy Indust., Ltd., 603 P.2d 765 (Or. 1979)

${ }^{93}$ See cases cited supra notes 12-14 and accompanying text.

${ }^{94}$ Miller, 945 P.2d at 1110 (quoting Billops v. Magness Constr. Co., 391 A.2d 196, 197-98 (Del. 1978)). 
inspectors and by its retained power to cancel the Agreement. That evidence would support a finding that defendant had the right to control the way in which $3 \mathrm{~K}$ performed at least food handling and preparation. In her complaint, plaintiff alleges that $3 \mathrm{~K}$ 's deficiencies in those functions resulted in the sapphire being in the Big Mac and thereby caused her injuries. Thus, ... there is evidence that defendant had the right to control $3 \mathrm{~K}$ in the precise part of its business that allegedly resulted in plaintiff's injuries. That is sufficient to raise an issue of actual agency. ${ }^{95}$

Notably the above passage gives weight to the inspection and termination enforcement powers of the franchisor. Additionally, the fact that food preparation and safety must be of central concern to fast food franchisors may have made it easier for the court to see the probability of intense franchisor interest in control or a right to control franchisee behavior.

Perhaps other matters, such as control over premises safety, are less obvious candidates for jury consideration than food preparation and handling. Still, customer safety from the various hazards arising in the course of being patrons of a franchised restaurant should be of great importance to a franchisor and worthy of attention and control. Courts should be wary of illusions to the contrary that lead to summary judgments.

For whatever reason, the Miller analysis is not encumbered by specious arguments based on the Lanham Act that were discussed earlier. ${ }^{96}$ Nor does the court make questionable assumptions about the actual control relationship between the franchisor and franchisee, which would ease the way to a summary judgment for the franchisor. A major difficulty in this area of the law is to formulate and apply legal principles to encourage franchisors to help franchisees achieve safety for customers. Franchisors have such strong business incentives to encourage and insist upon safe practices by franchisees that it is hard to imagine that in reality they are not doing so.

\section{Apparent Agency and Estoppel}

It is lunchtime and a driver is hungry. He sees a familiar sign along the highway advertising a well-known fast food restaurant and he sees the signs of two other restaurants unknown to him. Feeling safer with the familiar, he patronizes the well-known place. He becomes ill from the food he eats and files suit against the franchisor of the enterprise. The franchisor moves for summary judgment

\footnotetext{
${ }^{95}$ Id. at 1111.

96 See supra note 62 and accompanying text.
} 
claiming it is not liable for the torts of the franchisee who owns and operates the restaurant. Nor, it says, is it liable for the torts of the employees of that franchisee.

In the previous section, theories of franchisor liability based on the respondeat superior doctrine or analogies to its principles were considered. This section focuses on cases in which the question of franchisor liability for franchisee torts is based on apparent authority (or apparent agency) principles and gives brief consideration to liability based on estoppel.

In Miller v. McDonald's Corp., discussed above, the Oregon Court of Appeals used the Restatement (Second) of Agency, section 267 (Section 267) regarding apparent agency in arriving at its decision. ${ }^{97}$ Section 267 states:

One who represents that another is his servant or other agent and thereby causes a third person justifiably to rely upon the care or skill of such apparent agent is subject to liability to the third person for harm caused by the lack of care or skill of the one appearing to be a servant or other agent as if he were such. ${ }^{98}$

The Miller court referred to cases in which courts found a jury issue on apparent agency and stated that "[ $[\mathrm{t}] \mathrm{he}$ crucial issues are whether the putative principal held the third party out as an agent and whether the plaintiff relied on that holding out." ${ }^{\prime 99}$ The Miller court summarized these previous apparent agency cases:

In each of these cases, the franchise agreement required the franchisee to act in ways that identified it with the franchisor. The franchisor imposed these requirements as part of maintaining an image of uniformity of operations and appearance for the franchisor's entire system. Its purpose was to attract the patronage of the public to that entire system. The centrally imposed uniformity is the fundamental basis for the courts' conclusion that there was an issue of fact whether the franchisors held the franchisees out as the franchisors' agents. ${ }^{100}$

The Miller court pointed to the appearance and operation of the franchisee, in the case under consideration, as identifying it with the franchisor (McDonald's Corporation) and the common image for all of the latter's restaurants created through national advertising, common signs and uniforms, common menus, common appearance, and common standards. ${ }^{101}$ Regarding the possible existence

\footnotetext{
${ }^{97}$ Miller, 945 P.2d at 1111-12.

98 Restatement (Second) of Agency $\$ 267$ (1958).

99 Miller, 945 P.2d at 1112.

${ }^{100} \mathrm{Id}$. at $1112-13$.

${ }^{101} \mathrm{Id}$. at 1113.
} 
of a sign in the restaurant identifying the franchisee as the operator, the court quite wisely noted that fact issues remained as to "whether that sign was sufficiently visible to the public ... and ... whether one sign by itself is sufficient to remove the impression that [McDonald's] created through all of the other indicia of its control that it, and [the franchisee] ..., presented to the public." 102

Noting the franchisor (McDonald's Corporation) did not seriously dispute that a jury could find it held the franchisee $(3 \mathrm{~K})$ out as its agent, the court turned to the franchisor's argument that "there [was] insufficient evidence that plaintiff justifiably relied on that holding out." ${ }^{103}$ The plaintiff had taken the position that she went to the franchisee's $(3 \mathrm{~K}$ ) restaurant because it was a McDonald's restaurant, but the franchisor contended she also had to prove that she went to it because she believed McDonald's Corporation operated both it and the other McDonald's restaurants she had previously patronized. ${ }^{104}$ The court wisely rejected that standard, noting that it "demands a higher level of sophistication about the nature of franchising than the general public can be expected to have and ignores the effect of its own efforts to lead the public to believe that McDonald's restaurants are part of a uniform national system of restaurants with common products and common standards of quality." ${ }^{105}$ The court properly held it to be a jury question as to whether the plaintiff "believed that all McDonald's restaurants were the same because she believed that one entity owned and operated all of them or, at the least, exercised sufficient control that the standards that she experienced at one would be the same as she experienced at others." ${ }^{106}$

\section{A. The Restatement (Third) of Agency and Section 267}

There are cases in addition to Miller that accept the doctrine of apparent agency as applicable to franchisor liability claims, and cases often cite Section 267 for apparent agency principles.

Before further discussion of the application of apparent agency principles by courts, it is appropriate to consider the fate of Section 267 at the hands of the adopters of Restatement (Third) of Agency. The Restatement (Third) of Agency simply contains no section tracking Section 267. Whether the omission will have much of an impact on judicial views of apparent agency remains to be seen. However, for the reasons outlined below, the omission of Section 267 alone will not easily destroy its precedential value.

\footnotetext{
102 Id.

103 Id.

104 Id.

105 Id.

106 Id.
} 
First, those courts that have adopted principles akin to those set forth in Section 267 would need to be convinced that precedent should be overturned or altered before they disavow any of those principles. Second, courts lacking apparent agency precedent may be guided by principles of apparent agency derived from Section 267 and adopted by courts of other jurisdictions if they find them persuasive. Third, the absence of Section 267 language does not constitute in itself a repudiation of the principles of that section. Fourth, Restatement (Third) of Agency does not express hostility to the use of apparent agency principles that have evolved. Fifth, even if such omission were interpreted as an implicit repudiation of Section 267 in whole or in part, courts may choose to follow the principles of Section 267 especially in light of existing case law. Sixth, arguably, by omitting language tracking Section 267, Restatement (Third) of Agency is sending no discernible message.

Seventh, potentially of considerable significance, there exists case law involving hospital liability supporting the proposition that the omission of Section 267 language has opened the door wider to the trial of apparent agency actions in tort cases. This case law looks to section 2.03 of the Restatement (Third) of Agency (Section 2.03), as applicable in dealing with apparent authority claims. ${ }^{107}$

\section{B. Restatement Guidance}

Despite the fact that Restatement (Third) of Agency does not contain an "apparent agency" section equivalent to section 267 of the Restatement (Second), the Restatement (Third) of Agency nonetheless offers criteria applicable in making an apparent agency determination. Although courts often accept apparent agency as a basis for liability, some of them apply its principles so narrowly as to eliminate claims against franchisors for franchisee torts. ${ }^{108}$ Assuming that courts continue to accept apparent agency principles, appropriate guidance for making an apparent agency determination may be found in Restatement (Third) of Agency. This would be so unless, as seems unlikely, silence is construed as a repudiation of the principles of Section 267 and guidance from the Restatement (Third) of Agency or its comments on the meaning or application of apparent agency principles is deemed to be inappropriate in franchise cases.

To begin with, it is reasonable to assume that criteria for what is labeled as apparent authority should apply as well to apparent agency determinations from Restatement (Third) of Agency. Aside from the logical support for such an approach, comment b to Section 2.03 states, "[m]any judicial opinions use the

107 See generally Jones v. Healthsouth Treasure Valley Hosp., 206 P.3d 473 (Idaho 2009); Estate of Cordero v. Christ Hosp., 958 A.2d 101 (N.J. Super. Ct. App. Div. 2008); discussion infra accompanying notes 174-92.

108 See discussion infra accompanying notes 117-40. 
terms 'apparent agency' and 'apparent authority' interchangeably." ${ }^{109}$ Additionally, as indicated below, there is already case law supporting this approach in hospital liability cases. ${ }^{110}$

Section 2.03 and its comments afford useful guidance in interpreting apparent authority or apparent agency. For examples of such guidance from Restatement (Third) of Agency, consider the following:

1. Section 2.03 states: "[a]pparent authority is the power held by an agent or other actor to affect a principal's legal relations with third parties when a third party reasonably believes the actor has authority to act on behalf of the principal and that belief is traceable to the principal's manifestations." ${ }^{111}$ Clearly, a person need not actually be an agent to possess the power of apparent authority. The determination that really counts in asserting apparent authority is based on what a third party reasonably believes which is traceable to the principal's manifestations. ${ }^{112}$

2. The breadth of the principal's manifestations to be considered is illustrated by comment $\mathrm{c}$ to Section 2.03 which states in part:

The doctrine stated in this section applies to any set of circumstances under which it is reasonable for a third party to believe that an agent has authority, so long as the belief is traceable to manifestations of the principal. A principal's conduct does not occur in a vacuum. A third party's reasonable understanding of the principal's conduct will reflect general business custom as well as usage that is particular to the principal's industry and prior dealings between the parties. A belief that results solely from the statements or other conduct of the agent, unsupported by any manifestations traceable to the principal, does not create apparent authority unless, as explained below, the agent's conduct has been directed by the principal. An agent's success in misleading the third party as to the existence of actual authority does not in itself make the principal accountable. ${ }^{113}$

\footnotetext{
109 Restatement (Third) of Agency $\$ 2.03$ cmt. b (2006).

110 See cases discussed infra notes 174-96.

111 Restatement (Third) of Agency $\$ 2.03$ (2006).

112 See id.

${ }^{113}$ Id. $\$ 2.03 \mathrm{cmt}$. c.
} 
3. The term "manifestations" is defined in section 1.03 of the Restatement (Third) of Agency as follows: "A person manifests assent or intention through written or spoken words or other conduct." ${ }^{114}$ The comments to Section 2.03 explain "manifestations" as:

Manifestations as defined in $₫ 1.03$ may take many forms. These include explicit statements that a principal makes directly to a third party, as well as statements made by others concerning an actor's authority that reach the third party and are traceable to the principal. For example, a principal may make a manifestation about an agent's authority by directing that the agent's name and affiliation with the principal be included in a listing of representatives that is provided to a third party. The principal may make a manifestation by directing an agent to make statements to third parties or directing or designating an agent to perform acts or conduct negotiations, placing an agent in a position within an organization, or placing the agent in charge of a transaction or situation. ${ }^{115}$

4. The first reporter's note to Section 2.03 states in part:

In this Restatement, the definition of apparent authority incorporates by reference the definition of manifestation in $₫ 1.03$. The consequence intended is to eliminate any inference that, to create apparent authority, a principal's manifestation must be directed to a specific third person in a communication made directly to that person. ${ }^{116}$

\section{Apparent Agency Cases Illustrating Narrow Approaches}

Several cases illustrate narrow approaches to what can be regarded as sufficient evidence of apparent agency to overcome a summary judgment motion.

In Triplett v. Soleil, a husband and wife were plaintiffs on a claim arising from the husband contracting Legionnaires' disease allegedly from sources in a hotel owned by a franchisee of two franchisor defendants. ${ }^{117}$ The two franchisors were Sheraton, as to trademarks and logos, and Starwood, as to a reservations

\footnotetext{
${ }^{114} I d$. $\$ 1.03$. The comments to section 1.03 are extensive and enlightening.

115 Id. $\$ 2.03$ cmt. c.

${ }^{116} I d$. $\$ 2.03$ reporter's note a (2006).

117664 F. Supp. 2d 645, 647 (D.S.C. 2009).
} 
agreement. ${ }^{118}$ The court held that to recover against the franchisor(s) under an apparent agency theory, the plaintiffs would need to prove three elements: "(1) that Starwood or Sheraton consciously or impliedly represented to [the plaintiffs] that [the franchisee] acted as their agents; (2) that they relied upon the representation; and (3) that there was a change of position to their detriment." ${ }^{119}$ The franchisors sought summary judgment on the apparent agency claims. ${ }^{120}$

Reviewing some of the plaintiffs' arguments, the court stated:

As to the first element, Plaintiffs argue that Starwood and Sheraton represented the Hotel as its agent because they were never made aware of the Hotel's independent ownership in any of their dealings with it. Based on previous trips Plaintiffs have taken, they claim to be aware of the Sheraton and Starwood brands and first sought information about the Hotel through Sheraton's national website found at "www.sheraton.com." According to Plaintiffs, nothing on the website indicated that the Hotel was independently owned and operated. Mrs. Triplett also contacted the Hotel by telephone, and she was never informed that Main Street and Soleil Group actually owned and operated the Hotel. Plaintiffs also contend that the informational packet they received from Yolanda Patterson, the Director of Catering for the Hotel, only contained references to Starwood and Sheraton and failed to disclose Main Street's ownership and Soleil Group's management of the Hotel. ${ }^{121}$

The court also stated:

As to the second and third elements necessary to establish an apparent agency, Plaintiffs argue that they reasonably relied upon these representations in selecting the Hotel as the venue for Mrs. Triplett's high school class reunion and would not have reserved the Hotel for this event had they known the Hotel was not owned and operated by Starwood and Sheraton. ${ }^{122}$

The court seemed impressed by the fact that the License and Brand Agreements required the hotel owner to disclose its independent ownership, although the court admitted the provisions of the Agreement "do not evidence

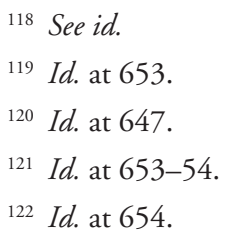


representations made by Starwood or Sheraton, as principals, to the plaintiffs, as third parties, which is the primary focus when determining whether an apparent agency relationship exists between a principal and its alleged agent." ${ }^{123}$ Still, the court-stretching its findings and relying on the testimony of an officer of the franchisors' quality control firm-inferred that the hotel had complied with the disclosures required by the License and Brand Agreements. ${ }^{124}$

The plaintiffs contended that even if a sign about independent ownership existed, they never saw it, and they never visited the hotel before reserving its facilities. ${ }^{125}$ Responding to the plaintiffs' claims that they had no notice of the hotel's independent ownership either in person or from the Starwood website, the court pointed to the terms and conditions for using the website, which stated:

This web site and the related web sites contained herein (collectively, the "Site") make available information on hotels, resorts, and other transient stay facilities (each a "Property") owned, managed or franchised by Starwood Hotels \& Resorts Worldwide, Inc. and/or its subsidiaries and affiliates. While this language did not specifically state that the Hotel which Plaintiffs used for the reunion was franchised, the above quoted language sufficiently represents that not all of the Starwood and Sheraton brand hotels are owned and managed by them. ${ }^{126}$

The court also pointed to a business card in an informational packet mailed to plaintiffs that stated, "albeit in very small type size," the hotel was independently owned and operated under a license issued by the Sheraton Corporation. ${ }^{127}$

Finally, the court summarized its position as follows:

After carefully reviewing the record, the court does not find that Plaintiffs have submitted evidence sufficient enough to create a genuine issue of material fact as to whether or not Starwood and Sheraton represented to them that Main Street and Soleil Group had the apparent authority to act as their agents. South Carolina precedent has refused to find that national advertising and brand name usage constitute a representation of apparent authority, and Starwood and Sheraton have provided evidence that several

\footnotetext{
123 See id. at 654-55.

124 See id. at 655.

${ }^{125} \mathrm{Id}$.

${ }^{126} \mathrm{Id}$. at 656.

${ }^{127} \mathrm{Id}$.
} 
placards were displayed throughout the Hotel that disclosed the Hotel's independent ownership. Moreover, the 'Terms and Conditions' of Starwood's website and the business cards used by the Hotel's employees expressly represented to Plaintiffs, as well as other potential guests, that certain hotels operating under the Starwood and Sheraton brand names are independently owned and that the Hotel in question was one of them. Therefore, Starwood and Sheraton are entitled to summary judgment on Plaintiffs' claims that Main Street and Soleil Group acted as their apparent agents. ${ }^{128}$

Thus, the law of South Carolina, as characterized above, restricts the concept of apparent authority by excluding evidence clearly relevant to the apparent agency determination. Moreover, the court otherwise resolved fact issues about apparent authority in an exceptionally narrow and unconvincing manner.

In another case, Mobil Oil Corp. v. Bransford, the Florida Supreme Court established a factual presumption without expressing any evidentiary basis for its position. ${ }^{129}$ The court used this presumption to bar an apparent agency claim against Mobil Oil Corporation (Mobil) at the summary judgment stage. ${ }^{130}$

In Mobil Oil, the plaintiff entered a Mobil Mini Mart gas station owned by Mobil but leased to an individual who was also a Mobil franchisee. ${ }^{131}$ One of the franchisee's employees attacked and beat the plaintiff, who subsequently sued Mobil on an apparent agency claim. ${ }^{132}$ The court explained apparent agency principles as follows:

In cases of alleged apparent agency, something must have happened to communicate to the plaintiff the idea that the franchisor is exercising substantial control. Our law is well settled that an apparent agency exists only if each of three elements are present: (a) a representation by the purported principal; (b) a reliance on that representation by a third party; and (c) a change in position by the third party in reliance on the representation. ${ }^{133}$

\footnotetext{
${ }^{128}$ Id. at 657.

129 See 648 So. 2d 119 (Fla. 1995).

${ }^{130}$ Id. at 120.

${ }^{131} \mathrm{Id}$.

${ }^{132} \mathrm{Id}$.

${ }^{133}$ Id. at 121 (citations omitted).
} 
The court applied those principles plus its presumption to bar plaintiff's suit as follows:

It is the first of these elements that is primarily relevant here. The factual allegations in the complaint below clearly fail to allege even the minimum level of a "representation" necessary to create an apparent agency relationship. The plaintiff below alleged no genuine factual representation by Mobil, but merely assumed that such a representation is implicit in the prominent use of Mobil symbols and products throughout the station and in the provision of support activities. As noted above, such an assumption is not sustainable in today's world. Unless properly amended, the complaint below clearly fails to state a cause of action against Mobil. ${ }^{134}$

The presumption of what is "well understood" about franchises in today's world is evidently the following:

We find Bransford's allegations legally insufficient to plead a case against Mobil. In today's world, it is well understood that the mere use of franchise logos and related advertisements does not necessarily indicate that the franchisor has actual or apparent control over any substantial aspect of the franchisee's business or employment decisions. Nor does the provision of routine contractual support services refute this conclusion. Here, the contract itself expressly stated that [the franchisee] "is an independent businessman, and nothing in this contract shall be deemed as creating any right in [Mobil] to exercise any control over, or to direct in any respect, the conduct or management of [the] business." 135

Thus, without indicating any evidentiary basis, the Court assumed a degree of sophistication and knowledge on the part of customers about the roles of the various actors who are advancing the business interests of each other and their enterprises as well as the nature of franchising in general and this franchise in particular. Such an assumption is not a reasonable or appropriate basis for summary judgment.

In Allen v. Choice Hotels, a hotel guest sued individually and as a wrongful death heir of her husband for his death and her injuries allegedly sustained during

\footnotetext{
${ }^{134} \mathrm{Id}$.

135 Id. at 120.
} 
a struggle with robbers in their hotel room. ${ }^{136}$ Among the defendants was the hotel franchisor that sought and won a summary judgment in its favor on all claims. ${ }^{137}$ The court referred to Mississippi cases finding vicarious liability where "a party holds itself out as offering services to the public and ... consumers are reasonably led to believe that they are doing business with that party ...." 138 The court favored the franchisor, however, stating it required the franchisee to display a sign in a prominent location in the hotel lobby indicating an independent party operated the hotel. "Therefore, Choice did not lead the public to believe that customers were doing business with Choice." ${ }^{139}$ This language of the court appears to bar an apparent agency claim from prevailing because of a simple finding that the franchisor required a sign in the lobby.

Such an approach is unduly narrow in making the apparent agency determination; surely, an agreement between a franchisor and franchisee requiring a lobby sign cannot be conclusive. Courts should still need to determine if and where the sign was placed, and even when such signs are present, courts should not presume the signs are sufficient to overcome the impact of other apparent agency manifestations. Such manifestations (including the franchisee's use of franchisor logos and trademarks, the franchisee's inclusion on the franchisor's website, the franchisee's use of the franchisor's uniform building and product requirements, etc.) may cause a customer to reasonably believe she is dealing directly with the franchisor.

Using summary judgment to reject a plaintiff's apparent agency claim against a franchisor because of a disclaimer in a lobby, or because certain manifestations traceable to the franchisor or franchisor requirements are excluded from the "holding out" determination, violates the spirit and letter of what is "apparent" to a third party for agency law purposes. The spirit and letter are further violated when a court creates an unsupported conclusive presumption, as in the Mobil case, that customers in "today's world" possess a sophisticated understanding of franchise relationships. ${ }^{140}$ Cases taking such a narrow view of "holding out" manifestations are refusing to apply reasonable apparent authority or apparent agency principles in franchisor cases.

\section{Apparent Agency Cases Illustrating Broader Approaches}

In contrast to the narrow approaches to apparent agency taken by cases considered in the previous subsection are the broader approaches illustrated by cases in this subsection. As an example the Miller case, discussed above, is truer

\footnotetext{
136942 So. 2d 817, 819-20 (Miss. Ct. App. 2006).

${ }^{137}$ Id. at 820 .

${ }^{138}$ Id. at 827 (quoting Fruchter v. Lynch Oil Co., 522 So. 2d 195, 200 (Miss. 1988)).

${ }^{139}$ Id.

140 See Mobil Oil Corp. v. Bransford, 648 So. 2d 119, 120 (Fla. 1995).
} 
to the manifestation and reasonable belief requirements of apparent agency. ${ }^{141}$ Similarly, in Butler v McDonald's Corp., a federal district court dealing with the application of the apparent agency doctrine to a franchisor stated, among other things, that it would require the plaintiff to prove the franchisor acted in a manner that would lead a reasonable person to conclude the operator and employees of the franchise restaurant were employees or agents of the defendant. ${ }^{142}$ The court approvingly discussed the Miller approach:

The [Miller] Court described examples of defendant's behavior that could lead a reasonable person to believe that the franchise restaurant was an agent of the defendant franchisor. These included all means and methods that would maintain an "image of uniformity" among all of defendant's restaurants, including "national advertising, common signs and uniforms, common menus, common appearance, and common standards." ${ }^{143}$

In Butler, the plaintiff raised arguments that mirrored the reasoning in the Miller case:

Plaintiff argues that defendant encourages third persons to think that they are dealing with defendant when they visit one of defendant's franchised restaurants. This belief stems from a customer's difficulty in differentiating between a restaurant that is corporate-owned from one which is franchised. Plaintiff points to defendant's national advertising campaign, highly visible logos throughout the restaurant and on food packaging, a requirement that the employees wear uniforms of designated color, design and other specifications, and volumes of required standards with respect to nearly all aspects of the franchise restaurant's maintenance, appearance, and operation. Seemingly, the purpose of defendant's mandatory procedures and requirements for the appearance and operation of franchised restaurants is to promote uniformity in both product and environment. ${ }^{144}$

The Butler court held that the plaintiff produced enough evidence to support the view that a reasonable person would conclude the operator and, or, employees of the franchise restaurant were employees or agents of the franchisor defendant. Thus, the court held the issue of apparent agency constituted a jury question. ${ }^{145}$

\footnotetext{
${ }^{141}$ See generally supra notes 90-95 and 97-106 and accompanying text.

${ }_{142}$ Butler v. McDonald's Corp., 110 F. Supp. 2d 62, 69 (D.R.I. 2000).

${ }_{143} \mathrm{Id}$.

${ }^{144} I d$. at 70.

${ }^{145} \mathrm{Id}$.
} 
The court also concluded there were jury questions as to what the plaintiff actually believed:

[P]laintiff has indicated that he simply went to the franchise restaurant because he and his friends wanted "McDonald's" food, as they had done on numerous occasions. Nowhere does plaintiff indicate that he did or could differentiate a franchised restaurant from a corporate-owned restaurant. Therefore, whether plaintiff actually believed that the franchise restaurant operator and/or his employees were agents of defendant is a question of fact best left for trial and resolution by the jury. ${ }^{146}$

Finally, the court likewise held that the question of whether the plaintiff relied to his detriment upon the care and skill of the allegedly negligent operator and/or employees of the restaurant presented a factual issue. ${ }^{147}$ Thus, the Butler court found issues of material fact with respect to all three prongs of the apparent agency inquiry and denied the franchisor's (McDonald's) motion for summary judgment. ${ }^{148}$

Lopez v. El Palmar Taxi, Inc., a 2009 Georgia case, involved a passenger injured in a traffic accident who sued a taxi company seeking to impose liability for a driver's alleged negligence. ${ }^{149}$ Although the driver was an independent contractor and not an employee of the company, the Court of Appeals of Georgia found that a genuine issue of material fact, regarding whether the driver was the apparent agent of the company, precluded summary judgment. ${ }^{150}$

In Lopez, the plaintiff contended that the El Palmar company should be held liable for negligence by the driver because it held its drivers out to the public as employees by advertising in the local phone book and by using business cards bearing the company's, not the driver's, name. ${ }^{151}$ The court cited the doctrine of apparent agency and Section 267 in holding that a party may prove a claim of agency through evidence of circumstances, apparent relations and the conduct of the parties. ${ }^{152}$ Discussing the circumstances of the instant case, the court observed:

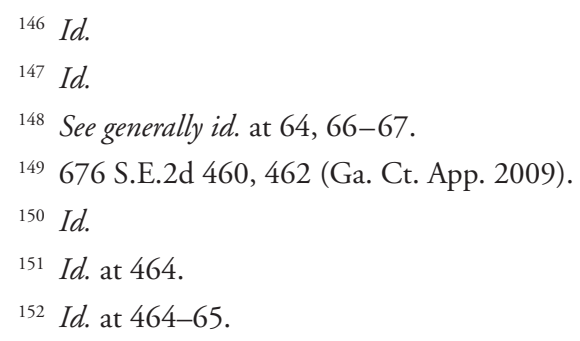


El Palmar does not dispute that it advertised its taxi services in the local telephone book. El Palmar also had business cards bearing the company name that were made available to the drivers to give to passengers. Further, El Palmar admitted that [the plaintiff] "called El Palmar Taxi seeking a taxi to pick her up" and that a taxi displaying its own El Palmar logo picked up [the plaintiff] and her children. ${ }^{153}$

The court also referred to language from a concurring opinion in another case stating "[in] many instances, passengers undoubtedly choose to ride in cabs apparently owned and operated by established companies because they assume that such cabs are safer and more reliable than cabs wholly owned and operated by individual drivers." 154 The court stated, "[v]iewing the undisputed facts in the light most favorable to [the plaintiff] ... . , we conclude that the existing record does not show that El Palmar was entitled to summary judgment." 155

In Thomas v. Freeway Foods, a race discrimination action under federal law, the court looked to North Carolina law in deciding that the question of an apparent agency relationship between the franchisee (Freeway Foods, Inc.) and the franchisor (Waffle House, Inc.) precluded a summary judgment in favor of the latter. ${ }^{156}$ The court explained the apparent agency issues as follows: "To establish liability based on apparent agency, 'a plaintiff must show that (1) the alleged principal has represented or permitted it to be represented that the party dealing directly with the plaintiff is its agent, and (2) the plaintiff, in reliance on such representations, has dealt with the supposed agent."'157

In finding the plaintiffs' evidence was sufficient to support submission to the jury on the theory of apparent agency, the court said:

Plaintiffs point out that, with the exception of the signs, Freeway Foods' Salisbury Waffle House represents itself to the public in exactly the same way as Waffle House owned and operated restaurants ... Plaintiffs, here, point out that the Waffle House name and mark appear throughout the Freeway Foods' restaurant, from the exterior signs to the menu, the employees' uniforms and name tags, and multiple interior signs. Additionally, Plaintiffs point to the Waffle House website,

153 Id. at 465.

154 Id. at 465 n.25 (citing Loudermilk Enters., Inc. v. Hurtig, 449 S.E.2d 141 (Ga. 1994)).

155 Id. at 465.

156 Thomas v. Freeway Foods, Inc., 406 F. Supp. 2d 610, 618-19 (M.D.N.C. 2005).

157 Id. at 618 (quoting Crinkley v. Holiday Inns, Inc., 844 F. 2d 156, 166 (4th Cir. 1988) (citing Restatement (Second) of Agency $\$ 267$ (1958))). 
www.wafflehouse.com, which provides a store directory of all Waffle House restaurants that does not distinguish between Waffle House owned restaurants and those that are franchised. ${ }^{158}$

Waffle House argued there could be no finding of apparent agency because of signs in the restaurant announcing that Freeway Foods was the operator and franchisee. The court refused to accept the position that the signs would bar the apparent agency claim:

While each party argues about the significance of the signs, there has not been sufficient evidence presented at this stage of the proceeding to support a ruling as a matter of law. There are still open questions about the size and placement of the signs in relation to customers and whether most customers would likely have seen them and, thereby, have understood that the restaurant was neither owned nor being operated by Waffle House. ${ }^{159}$

The court also felt the evidence presented by plaintiffs on the reliance prong of the apparent agency test was sufficient, saying:

Plaintiffs explained that they chose to go to the Salisbury Waffle House because they saw the sign the night before and recognized it as a restaurant chain where they had eaten at before and enjoyed the food. Additionally, Ms. Thomas testified that because of her health requirements, she chose to go to Waffle House because she "could get food cooked the way she needed." . . . Finally, Ms. Willis, Mr. Willis and Ms. Thomas all stated that if they had known that the Waffle House was owned and operated by another party they would not have decided to eat there. Thus, Plaintiffs' reliance on their previous experiences with Waffle House restaurants played a large role in their decision to eat at the Salisbury restaurant. ${ }^{160}$

In Miles v. Century 21, a 2007 federal district court decision, the plaintiffs, an African-American couple serving in the U.S. Air Force, claimed that a franchisor, Century 21 Real Estate, LLC (Century 21), was vicariously liable for violations by a franchisee, to which the court referred as Century 21 Cabot, of federal and state anti-discrimination laws. ${ }^{161}$ The alleged violations occurred in connection

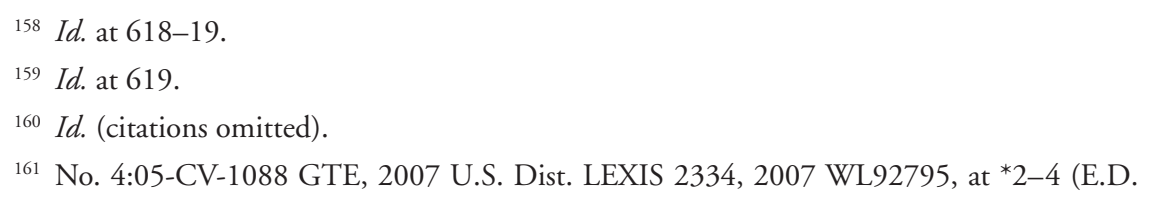
Ark. Jan. 11, 2007). 
with the plaintiffs' efforts to lease a house in Arkansas. ${ }^{162}$ The court denied Century 21 's motion for summary judgment with respect to plaintiffs' apparent agency claim. ${ }^{163}$

In denying the motion, the court cited with evident approval the following legal analysis:

To apply the doctrine of apparent agency to a franchisor/ franchisee situation, the plaintiff must prove: (1) that the franchisor acted in a manner that would lead a reasonable person to conclude that the operator and/or employees of the franchise were employees or agents of the defendant; (2) that the plaintiff actually believed the operator and/or employees of the franchise were agents or servants of the franchisor; and (3) that the plaintiff thereby relied to his or her detriment upon the care and skill of the allegedly negligent operator and/or employees of the franchise. Examples of a franchisor's behavior that could lead a reasonable person to believe that a franchisee is an agent of the franchisor include all means and methods that would maintain an image of uniformity among all of the franchises, including national advertising, common signs and uniforms, common menus, common appearance, and common standards. ${ }^{164}$

Among the factors the court considered important to include in explaining its determination are the following:

In support of their assertion that the doctrine of apparent agency applies in this case, Plaintiffs submit the deposition testimony of Mr. Thomas Kunz, the President and Chief Executive Officer of Century 21 Real Estate LLC, where he states that Century 21 is the "most recognized real estate sign in the world," and the logo, as a brand, "conveys ... some kind of minimum expectation that we would -- that a consumer would expect to received [sic] from anybody that would have that brand." Plaintiffs also argue that Ms. Shown, the owner of Century 21 Cabot, states that when she purchased Century 21 Cabot, she received " $[\mathrm{g}]$ oodwill. I got a nationally recognized company name." Plaintiffs state that the Century 21 logo, marks, name, and symbols are used extensively by Century 21

${ }_{162} I d$. at ${ }^{*} 2$.

${ }^{163} I d$. at $* 39-40$.

${ }^{164}$ Id. at *26 (quoting 62B AM. Jur. 2D, Private Franchise Contracts $\$ 300$ ) (internal citations and internal quotation marks omitted). 
Cabot, and Century 21 provides precise specifications for the use of its proprietary marks." 165

Also of particular significance to the court's apparent agency disclaimer analysis was the following:

Plaintiff Joseph Miles also states that he did not observe the disclaimer that each office is "independently owned and operated" on the sign in front of the house, Ms. Ward's business card, or in the Century 21 Cabot office, but even if he had observed such a statement, he does not understand the legal consequences of such a statement. ${ }^{166}$

This forthright admission of the plaintiff about a lack of understanding points not merely to his own subjective belief, but raises a general question about the degree of sophistication which customers are expected to have when a technical disclaimer is used to rebut impressions created by other representations.

A recently decided case, Ross $v$. Choice Hotels International, Inc., illustrates a realistic approach by the court in denying defendant franchisor's motion for summary judgment. ${ }^{167}$ In Ross, plaintiffs were not allowed to use the room they rented at a Comfort Suites East Hotel in Ohio as they wished. They left the hotel and were denied a refund. They sued Choice Hotels International, Inc. (Choice), franchisor of the hotel, as well as the hotel franchisee and management companies. Among the plaintiffs' claims were those filed against Choice on the basis of Ohio apparent agency law for unlawful discrimination under federal and state statutes. ${ }^{168}$ In denying a summary judgment motion by Choice, the court held inter alia that plaintiffs' apparent agency claim was worthy of jury consideration. ${ }^{169}$ In reaching this decision the court reviewed plaintiffs' suggestion that a reasonable jury could find on the evidence before the court that Choice permitted the franchisee and management companies to hold themselves out to the public as acting on behalf of Choice, that plaintiffs believed they were interacting with Choice and that plaintiffs had good faith reasons to believe the franchisee and management companies had the authority to act on behalf of Choice.

The court noted that plaintiffs submitted the franchise agreement and rules indicating Choice's requirements mandating the franchisee to "use Comfort Suites signage and logos inside and outside the hotel" and also noted "the Choice

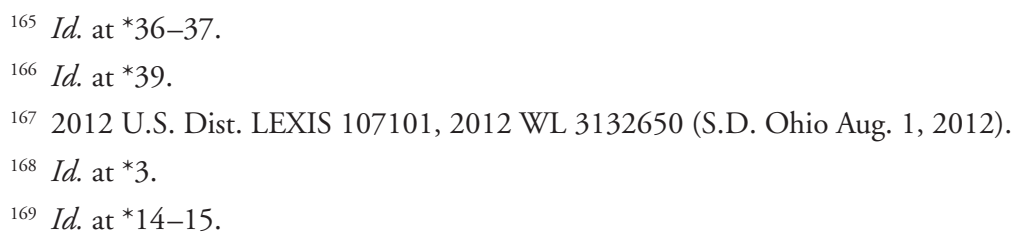


directory and website listings as identifying the hotel only as a Comfort Suites Hotel." ${ }^{170}$ (The court raised the possibility that only the former contention presented much relevance regarding plaintiffs' perceptions and reliance since the evidence indicated only that they saw the signage and logos inside and outside the hotel). The court also noted that plaintiffs contended they went to the hotel because of the Comfort Suites sign visible from the road, they did not know the hotel was independently owned, the employee they dealt with wore a Comfort Suites uniform and their receipt bore the Comfort Suites logo. ${ }^{171}$

Citing several cases the court stated that "[p]ersuasive authority supports the denial of summary judgment based on such facts given that a jury could rely on them in finding apparent agency." ${ }^{172}$

The court acknowledged Choice's argument that it did not hold out the franchisee and management companies as its agents but they held themselves out, but the court responded: "What Choice Hotels does not credit is that reasonable inferences suggest that Choice Hotels enabled if not actively endorsed such holding out; that is the point of apparent agency, or agency by estoppel." ${ }^{173}$ To the court's view of the franchisor as the possible enabler or active endorser of the holding out, there should be added the possibility that at times a franchisor not only enables or endorses but also actually requires the holding out.

At this point, it is well to consider hospital liability cases, which accept a possible and not unreasonable interpretation of the principles of apparent agency (referred to as apparent authority) in tort cases. Although these cases do not involve franchisor-franchisee relationships, the principles of apparent agency applied in these hospital cases may logically be applied to other apparent agency determinations, including those in franchise cases. Of course, some courts may reject the position of these hospital liability cases or distinguish franchise cases in some way.

In Estate of Cordero v. Christ Hospital, the estate and husband of a deceased patient sued a hospital alleging vicarious liability for the negligence of an anesthesiologist. ${ }^{174}$ The plaintiffs contended that the hospital was liable under a theory of apparent authority. ${ }^{175}$ The trial court dismissed the plaintiffs' claim because of the absence of evidence that the hospital actively held out the doctor

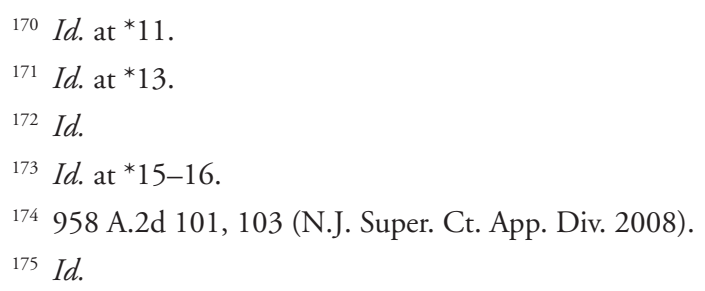


involved as its agent or misled the patient about his agency. ${ }^{176}$ On appeal, the Appellate Division of the New Jersey Superior Court rejected the trial court's position. ${ }^{177}$ The appellate court's discussion of apparent authority in the context of the hospital cases makes the following points:

1. Liability could be imposed on the principal because of its somehow misleading the public into believing that the relationship or the authority exists. ${ }^{178}$

2. Apparent authority is demonstrated when the hospital by its actions held out a person as its agent and/or employee and the patient accepted treatment in the reasonable belief that it was rendered on behalf of the hospital. ${ }^{179}$

3. A hospital can hold out a doctor as its agent without actively misrepresenting the agency or affirmatively misleading the patient, such as where the hospital provided doctors to treat an emergency. ${ }^{180}$

4. Holding out is determined by considering the totality of the circumstances created by the hospital's actions. ${ }^{181}$

5. Consideration of the entire course of conduct and the impression it would convey to a reasonable patient in the same situation is consistent with Section $2.03^{182}$ and section 429 of the Restatement (Second) of Torts (Section 429). ${ }^{183}$

\footnotetext{
${ }^{176} \mathrm{Id}$. at 105.

177 Id.

${ }^{178}$ Id at 104.

${ }^{179} \mathrm{Id}$. at 103.

${ }^{180} \mathrm{Id}$. at 105.

${ }^{181}$ Id. at $107-08$.
}

182 Restatement (ThiRd) OF AgenCy $₫ 2.03$ (2006) (“Apparent authority is the power held by an agent or other actor to affect a principal's legal relations with third parties when a third party reasonably believes the actor has authority to act on behalf of the principal and that belief is traceable to the principal's manifestations.").

183 Estate of Cordero, 958 A.2d at 106. Section 429 reads as follows, "One who employs an independent contractor to perform services for another which are accepted in the reasonable belief that the services are being rendered by the employer or by his servants, is subject to liability for physical harm caused by the negligence of the contractor in supplying such services, to the same extent as though the employer were supplying them himself or by his servants." REsTATEMENT (SECOND) OF TORTS $\$ 429$ (1965). 
6. A principal may manifest assent to the agency by placing a person in a position from which third parties will infer that the principal assents to acts necessary to fulfill the responsibilities of the position. ${ }^{184}$

The court also noted that the patient must accept the agent's service reasonably believing that it is rendered on behalf of the principal. ${ }^{185}$ As to this point, by making the following statement, the court noted its view of a changed reliance requirement:

There is a notable difference between sections 2.03 and 429 and the standard for apparent authority provided in section 267 of the Restatement (Second) of Agency (1958), which includes an element of reliance. Reliance is an element of apparent authority under sections 2.03 and 429 only to the extent that it is subsumed in the requirement that the person accepting an agent's services do so in the "reasonable belief" that the service is rendered in behalf of the principal.

The elements of agency by estoppel also differ from the elements of apparent authority stated in sections 2.03 and 429. Agency by estoppel requires proof of detrimental reliance. ${ }^{186}$

Obviously, the court does not exclude facts from the "totality of circumstances" or create artificial impediments in determining the presence of "apparent authority" in the same manner displayed at times in franchise cases discussed earlier.

In another hospital case, Jones v. TVH, the Idaho Supreme Court succinctly stated the case required it "to consider whether a hospital can be found vicariously liable for the negligence of an independently contracted cell saver technician under Idaho's doctrine of apparent agency." 187 Preferring to use the term apparent authority instead of apparent agency, the court held "that a hospital may be found liable under Idaho's doctrine of apparent authority for the negligence of independent personnel assigned by the hospital to perform support services." ${ }^{\text {188 }}$ In so holding, the court cited sections from the Restatement (Second) of Torts and the Restatement (Third) of Agency:

\footnotetext{
${ }^{184} I d$. at 106-07 (citing Restatement (Third) of Agency $\$ 1.03 \mathrm{cmts}$. b, e (2006)).

${ }^{185} \mathrm{Id}$. at 106.

$186 \mathrm{Id}$. at 106 n.3 (citing Restatement (Third) OF AgenCy $\$ 2.05$ intro. note (2006)).

187206 P.3d 473, 474 (Idaho 2009).

${ }^{188} \mathrm{Id}$. at 475.
} 
Under section 429 of the Restatement (Second) of Torts, liability is imputed to a principal "who employs an independent contractor to perform services for another which are accepted in the reasonable belief that the services are being rendered by the employer or by his servants ...." 189 When determining liability in a situation such as this when an agency relationship is alleged, the Restatement (Second) of Torts defers to the Restatement of Agency. ${ }^{190}$ Section 2.03 of the Restatement (Third) of Agency defines "apparent authority" as "the power held by an agent or other actor to affect a principal's legal relations with third parties when a third party reasonably believes the actor has authority to act on behalf of the principal and that belief is traceable to the principal's manifestations." 191

Citing the Cordero case explanation of the reliance requirement of Section 2.03 and contrasting reliance requirements of Section 267 and agency by estoppel, section 2.05 of the Restatement (Third) of Agency (Section 2.05), the court concluded that "under the Restatement (Third) of Agency, [the] plaintiff is only required to prove reasonable belief rather than justifiable reliance, to satisfy a claim of apparent authority." ${ }^{192}$ The courts' references to estoppel in Cordero and Jones are noteworthy because of the possible use of the estoppel doctrine in franchisor cases.

Section 2.05 provides for estoppel as follows:

A person who has not made a manifestation that an actor has authority as an agent and who is not otherwise liable as a party to a transaction purportedly done by the actor on that person's account is subject to liability to a third party who justifiably is induced to make a detrimental change in position because the transaction is believed to be on the person's account, if

(1) the person intentionally or carelessly caused such belief, or

(2) having notice of such belief and that it might induce others to change their positions, the person did not take reasonable steps to notify them of the facts. ${ }^{193}$

189 Id. at 477 (quoting Restatement (SeCond) of Torts $₫ 429$ (1965)).

190 Id. (quoting Restatement (Second) of Torts $\$ 429 \mathrm{cmt}$. c (1965)).

${ }^{191} I d$. at 477-78 (quoting ResTatement (ThiRd) OF AgenCY $\$ 2.03$ (2006)). The importance of Restatement (Second) of Torts and Restatement (Third) of Torts Tentative Draft to franchisor liability cases is discussed later. See infra notes 201-04 and accompanying text.

192 Jones, 206 P.3d at 481 (relying on Restatement (Third) of Agency $\$ 2.03$ (2006)).

193 Restatement (Third) of Agency $\$ 2.05$ (2006). 
Those courts not satisfied that a franchisor's manifestations establish apparent authority may be willing to accept Section 2.05 as a basis of franchisor liability where the latter's responsibility is based on the estoppel doctrine. Comment $d$ to Section 2.05 states in part:

Apparent authority is not present unless the third party's belief is traceable to the principal's own manifestations, which may include placing the agent in a position that leads third parties to believe the agent has authority consistent with the position. ${ }^{194}$ Estoppel does not require as close a fit between affirmative acts of the principal and the third party's belief. Instead, it protects third parties who reasonably believe an actor to be authorized as an agent when the belief cannot be shown to follow directly or indirectly from the principal's own manifestations. ${ }^{195}$

As to the detrimental change of position requirement of Section 2.05, comment b states: "Detrimental change of position' means an expenditure of money or labor, an incurrence of a loss, or subjection to legal liability, not the loss of the benefit of a bargain." 196

Suppose a driver patronizes a well-advertised fast food restaurant because of confidence in the members of the franchise family created by publicity as well as good experience at other establishments with the same name. Suppose she suffers an injury because of a foreign object in her hamburger. Could she prevail under an apparent authority (or apparent agency) or estoppel approach? Could a franchisor walk away from responsibility to the victim who may be unable to recover her loss because of a judgment proof franchisee? Should the franchisor be allowed to escape responsibility for an injury caused by careless food preparation or in a fall down case because of careless floor cleaning? To what extent should a patron be able to look to a perceived enterprise for redress when she later learns that her perception was wrong?

A court that takes a narrow approach to what is apparent authority, because of a strict view as to what constitute manifestations by a principal, may be open to estoppel liability, which does not require as close a fit between the principal's affirmative acts and the third party's belief. It would appear that the detrimental change of position requirement would encompass the results to the tort victim.

Questions of law and policy need to be addressed forthrightly in dealing with franchisor cases. In many situations, the franchisor with its knowledge and power is in a good position to promote safety and the financial responsibility

\footnotetext{
${ }^{194} I d$. $\$ 2.05 \mathrm{cmt}$. d (referring to Restatement (Third) OF Agency $\$ 3.03 \mathrm{cmt}$. b (2006)).

${ }_{195}$ Id.

196 Id. cmt. b.
} 
of franchisees. Furthermore, customers often are understandably misled into thinking that they are involved in transactions with franchisors. Courts must determine the proper legal rules to encourage appropriate behavior by franchisors and franchisees. Courts must address summary judgment motions based on application of appropriate principles to properly determined facts. Alleged factual determinations that lack reality undermine the important requirement that persons can rely on courts to dispense impartial justice. If the apparent agency doctrine is properly applied to the case facts and this leads to results unacceptable to courts, then they must bravely face the need to alter the applicable doctrine.

\section{The Impact of the Restatement of TORTS On Franchisor LIABILITY CASES-APPARENT AUTHORITY}

As indicated above, there are cases that have used Section 267 as a basis for apparent agency claims against franchisors for physical harm torts caused by franchisees. ${ }^{197}$ Section 7.03 of the Restatement (Third) of Agency expressly allows for apparent authority tort claims on a limited basis and does not refer to liability from torts of non-agents. ${ }^{198}$ This section does not seem designed to cover or impact on the viability of the kind of claims formerly brought under Section 267 against franchisors.

The recent hospital liability cases, discussed above, ${ }^{199}$ interpret the Restatement changes as enhancing physical harm claims against apparent principals under apparent authority, Section 2.03, which has changed the reliance requirement. In addition, Section 2.03 applies to both agent and non-agent conduct. ${ }^{200}$ Arguably, claims against franchisors could be reasonably pursued under apparent authority Section 2.03 as analyzed in Cordero and Jones, the hospital liability cases.

Moreover, support for physical harm claims against persons who hire independent contractors who appear to be their employees exists under section 65 of the Restatement (Third) of Torts Tentative Draft (Section 65) ${ }^{201}$ as successor

197 See generally supra Section III at notes 174-96 and accompanying text (discussing Cordero and Jones cases).

198 Restatement (Third) of Agency $\$ 7.03$ (2006).

199 See generally supra Section III at notes 174-96 and accompanying text (discussing Cordero and Jones cases).

200 See supra note 182 and accompanying text.

201 See Restatement (Third) of Torts: Liab. for Physical \& Emotional Harm $\$ 65$ (Tentative Draft No. 7, 2011). Section 65 states:

An actor who hires an independent contractor to perform services is subject to vicarious liability for physical harm if:

(a) the services are accepted in the reasonable belief that the actor or the actor's employees are rendering the services, and 
to Section $429 .{ }^{202}$ As indicated above, both the Cordero and Jones cases refer to Section 429. In addition, the reporters' notes to Section 65 cite the Cordero case in explanation of the section. Furthermore the comment b to Section 65 states:

The rule in this Section . . . can be viewed as an application of the principle of apparent authority in contexts involving physical harm caused by an independent contractor. Apparent agency can be established by any set of circumstances under which it is reasonable for a third party to believe that the person has authority to act for another, so long as that belief is traceable to manifestations by the other. This section specifically requires that the actor hire an independent contractor to perform services, and that these services be accepted in the reasonable belief that the hirer or the hirer's employees are providing the services. ${ }^{203}$

Finally, the comments to Section 65 contain the following illustration:

Molly's brother, Charlie, faints. Molly hails a taxi, whose labeling indicates that it belongs to Clement Taxi Company. However, under the driver's arrangement with Clement Taxi Company, the driver is an independent contractor. Molly helps Charlie into the taxi and accompanies Charlie in the taxi as they head to the doctor's office. As a result of the taxi driver's careless driving, the taxi collides with another car, driven by Paul. Molly, Charlie, and Paul are all injured. Clement Taxi Company is subject to vicarious liability to Molly and Charlie, but not to Paul. ${ }^{204}$

For courts seeking American Law Institute guidance in franchisor apparent authority cases involving physical harm torts, Sections 2.03 and 429, and Tentative Draft Section 65, whether directly or by analogy are valuable.

\section{Franchisor TorTs-Direct Liability}

Until now, this article has focused on franchisor liability for franchisee torts. In contrast, this section deals with the direct liability of a franchisor for its own torts.

(b) the independent contractor's negligence is a factual cause of harm to one who receives the services and such harm is within the scope of liability.

${ }^{202}$ Id. cmt. a ("This section carries forward the principle contained in Restatement Second, Torts $₫ 429$.”).

${ }^{203}$ Id. cmt. b (referring to Restatement (Third) of Agency $\$ 2.03$ cmt. c (2006)) (internal citation omitted).

${ }^{204} I d$. cmt. e, illus. 4. 
As with vicarious liability, control issues may be central in direct liability cases. Thus, negligent selection by the franchisor of items the franchisee will use may lead to direct liability. For example, in Whitten v. Kentucky Fried Chicken Corp., the court referred to the franchise agreement requiring the franchisee to use equipment approved by Kentucky Fried Chicken Corp. (KFC) for the preparation of chicken. ${ }^{205} \mathrm{~A}$ franchisee employee injured in the use of a fryer sued the franchisor and others who allegedly approved its design. ${ }^{206}$ The trial court granted a summary judgment in favor of the franchisor, concluding, inter alia, that it owed no duty to the plaintiff. ${ }^{207}$ The appellate court cited section 414 of the Restatement (Second) of Torts, which states:

$[\mathrm{O}]$ ne who entrusts work to an independent contractor, but retains control of any part of the work, is subject to liability for physical harm to others for whose safety the employer owes a duty to exercise reasonable care, which is caused by his failure to exercise his control with reasonable care. ${ }^{208}$

The court explained it was for the trier of fact to determine to what extent the franchisor was able to control the operations of the franchisee and such control must consist of something more than a general right to make suggestions or recommendations or to order work stopped or resumed..$^{209}$ The court concluded that summary judgment was not appropriate because the instrumentality alleged to have caused the injury was one purchased with the approval if not at the direction of the franchisor. ${ }^{210}$ Furthermore, the court pointed to questions of material fact as to the degree of control or direction KFC retained over the equipment purchased by its franchisees and the franchise operation as a whole.

The Whitten court also proceeded with a different theory under section 324A of the Restatement (Second) of Torts dealing with "Liability To Third Person for Negligent Performance of [an] Undertaking." 211 The court stated that a jury could find KFC undertook to recommend or select a safe fryer for the use of employees of its franchisee and increased the risk to the plaintiff due to its failure to exercise reasonable care. ${ }^{212}$ The court also stated that the jury could find KFC undertook to perform a duty owed by the plaintiff's employer to the plaintiff, i.e.,

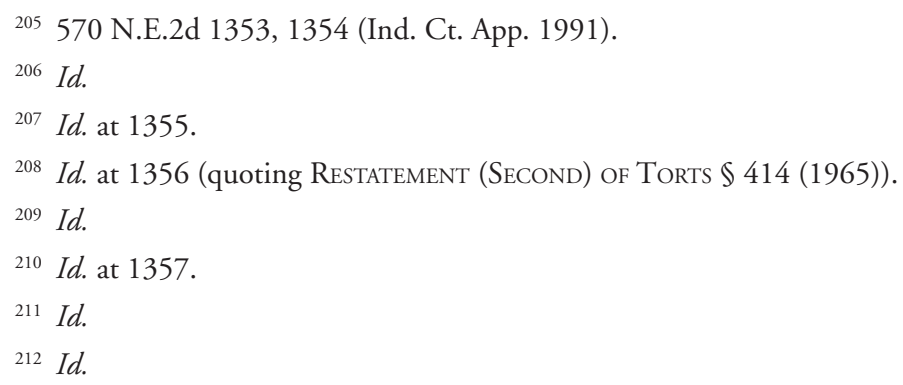


the recommendation or selection of safe equipment that employees would use. ${ }^{213}$ Additionally the court found that the franchise contract provided for the right to inspect to determine compliance with contract specifications, that KFC had exercised that right of inspection, and that therefore issues of fact needed to be resolved regarding liability under section 324A of the Restatement. ${ }^{214}$

The importance of franchisor control was also clear in Kosters $v$. The Seven- Up $C_{0}{ }^{215}$ In that case, a purchaser of soft drinks who was injured when a bottle slipped from its carton brought an action against the soft drink franchisor that had the right of control over the carton design. ${ }^{216}$ The court found the case had been properly submitted to the jury on both negligence and breach of implied warranty theories. ${ }^{217}$

Another type of franchisor control issue may arise from involvement in franchisee operations. In Allen v. Choice Hotels, a federal court pointing to South Carolina law held that a hotel franchisor did not owe a duty to hotel guests to direct the franchisee to retrofit hotels with sprinklers. ${ }^{218}$ The court set forth an interesting comparison between vicarious and direct liability analyses which turned upon franchisor control, saying: "Like the vicarious liability analysis, the '[d]irect liability cases [also] look to the franchisor's actual control or retained right of control to determine the presence of a duty for purposes of evaluating whether the franchisor was itself negligent." 219

The Allen court found neither the "Franchise Agreement" nor the "Rules and Regulations" established sufficient control to create a franchisor duty to hotel guests. ${ }^{220}$ The court also reviewed the issue of whether the franchisor, Choice Hotels, (Choice), owed a common law duty of care to foreseeable persons. Rejecting that position, the court found Choice did not create a risk or make injury to hotel guests more likely. ${ }^{221}$ Additionally, although the court recognized a duty under South Carolina law to use due care where an act is voluntarily undertaken for the benefit of a party, the court felt unable to find there was such an undertaking by Choice. ${ }^{222}$

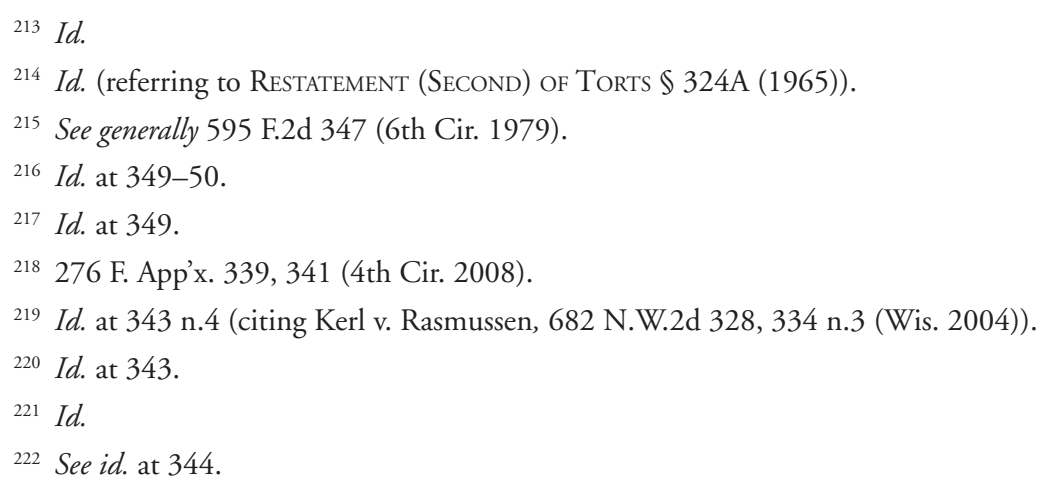


In Braucher ex rel Braucher v. Swagat, a hotel guest and the estate of a deceased guest filed a negligence action against a hotel franchisor and franchisee alleging the guests became ill with Legionnaires' disease following a stay at the franchised hotel. ${ }^{223}$ The plaintiffs' expert opined that if the defendants had performed their obligation to maintain the pool and spa, the plaintiffs would not have contracted the disease. ${ }^{224}$ Among its findings, the court held that the franchisor neither exercised sufficient control over the franchisee to be subject to a duty as an operator of the hotel nor voluntarily assumed a duty to maintain the pool and prevent infection. ${ }^{225}$ However, the court made the important statement that the face of an agreement is not controlling on the issue of duty because a franchisor may assert sufficient control of a hotel to be responsible for the operation of the pool and spa. ${ }^{226}$

In another case illustrating the importance of the control issue, Vaughn $v$. Columbia Sussex, the plaintiff asserted that she fell on a hotel lobby's wet floor while walking to a meeting with hotel management. ${ }^{227}$ She brought a negligence claim against the franchisor, Holiday Inn, and its franchisee. ${ }^{228}$ Holiday Inn moved for a summary judgment, arguing as a matter of law it bore no liability, because "liability in tort "cannot be ascribed in the absence of ownership or authority to remedy an alleged situation." ${ }^{229}$ Holiday Inn claimed it had "no authority" to remedy the situation involved in the case. ${ }^{230}$ The court referred to New York law, under which "[1]iability for a dangerous condition on property is predicated upon occupancy, ownership, control, or a special use of such premises." ${ }^{231}$ The court pointed to the franchisor's license agreement with the franchisee, which guaranteed substantial control by the franchisor. ${ }^{232}$ The court indicated that the franchisor was involved in the training of hotel employees and the construction of the hotel, that the franchisor could inspect the hotel at any time, and that the franchisor could order upgrading and rehabilitation pursuant to its own standards. ${ }^{233}$ Although there were not yet enough facts to determine whether the

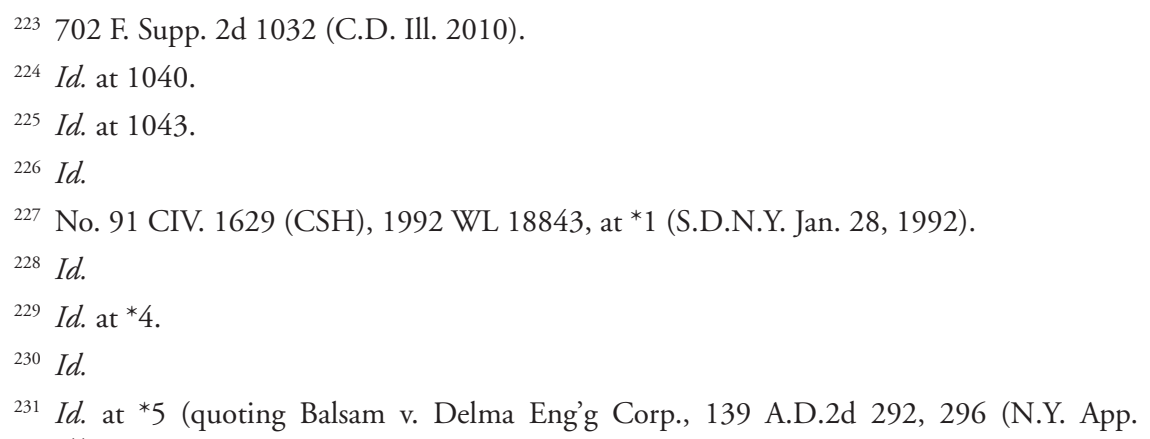

Div. 1988)).

${ }^{232}$ Id. at *4-5.

${ }^{233} \mathrm{Id}$. 
franchisor was liable to the plaintiff, the court stated that on a summary judgment motion the plaintiff need not make such a showing. ${ }^{234}$

Persons involved in the negligent creation of dangerous or defective conditions on property, even if not owners or possessors, may incur liability. In Walsh v. Super Value, Inc., a defendant, who was the owner of a Texaco gas station and convenience store, leased the premises to another defendant that ran the business. ${ }^{235}$ The owner and the lessee agreed to convert the Texaco station to a Shell station. ${ }^{236}$ The conversion required repainting several areas of the station including the curb outside the convenience store in accordance with requirements specified by Shell Oil Company and Shell Oil Products Company, LLC (referenced collectively as, Shell). ${ }^{237}$ Upon leaving the store, a customer slipped on the painted curb and sustained injuries. ${ }^{238}$ She filed suit against the aforementioned defendants and Shell, among others, claiming the paint on the curb created a dangerous or defective condition. ${ }^{239}$ Relying on rules of liability pertinent to an owner's creation of a dangerous or defective condition, the court rejected Shell's motion for summary judgment, even though Shell was not an owner of the property. ${ }^{240}$ The court spoke of the duty of an owner to maintain the premises in a reasonably safe condition. ${ }^{241}$ The court held:

[A]n owner should be held liable for the creation of a dangerous or defective condition on property if a reasonable person in the owner's position would have known, or would have had reason to know, of the danger created, or would have had such knowledge imputed by operation of law. ${ }^{242}$

Spring Tree Properties, Inc. v. Hammond also illustrates the vulnerability of a franchisor arising from the condition of the enterprise premises. ${ }^{243}$ In that case, the driver of a van approaching a Hardee's restaurant inadvertently stepped on her accelerator while attempting to park in a head-in parking space located directly in front of the restaurant. ${ }^{244}$ The van ascended the curb and hit the plaintiff,

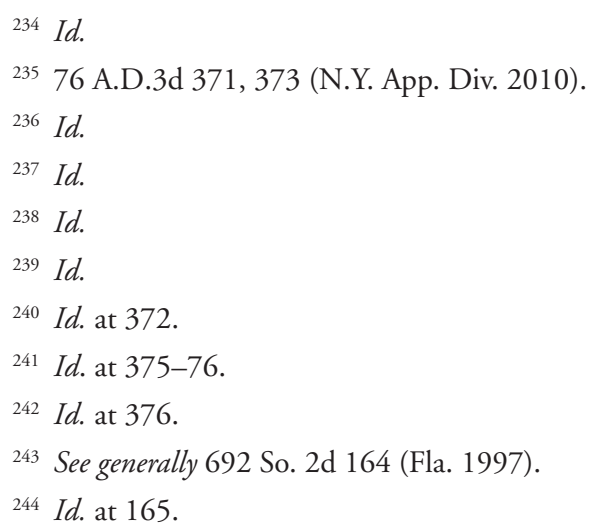


who was exiting the restaurant. ${ }^{245}$ Among the defendants were the franchisor (Hardee's) and its franchisee. ${ }^{246}$ The plaintiff alleged they had breached their duty of care by failing to maintain the premises in a reasonably safe condition; specifically, by failing to prohibit parking directly in front of the restaurant door, failing to provide an adequate barrier between the restaurant's front parking spaces and the front doors, failing to install vertical bumper posts in front of the restaurant's front parking spaces, failing to install wheel stops in the restaurant's front parking spaces, failing to provide a reasonably safe entrance/exit, failing to remedy a foreseeably unsafe condition, and failing to provide signs warning of unsafe conditions. ${ }^{247}$

The trial court granted summary judgment in favor of Hardee's and its franchisee. ${ }^{248}$ The intermediate appellate court reversed, and the Florida Supreme Court agreed that summary judgment was not appropriate, finding the record contained sufficient evidence to justify a reasonable person believing that the defendants breached their duty of care and that the breach was the proximate cause of the injury suffered. ${ }^{249}$ The Florida Supreme Court, while not relying on it as a reason for overturning the summary judgment, made clear that it would have been erroneous for the trial court to conclude Hardee's did not have a duty to protect the plaintiff from the specific harm involved in this case. ${ }^{250}$

It is evident from the discussion in this section that franchisor direct tort liability may arise in various ways. Indeed, issues of franchisor control or behavior with respect to operations or real and personal property involved in the franchised enterprise are key to determining such liability.

\section{CONCLUSION}

Summary judgment is a powerful tool, appropriate when no issue of material fact is presented. ${ }^{251}$ Yet, in granting summary judgments favorable to franchisors,

\footnotetext{
${ }^{245} \mathrm{Id}$.

${ }^{246} \mathrm{Id}$.

247 See id. at 166.

${ }^{248} \mathrm{Id}$.

${ }^{249}$ See id. at 168.

${ }^{250} \mathrm{Id}$. at 166.
}

${ }^{251}$ Fed. R. Civ. P. 56. While the 2010 amendments to the Federal Rules of Civil Procedure replaced the word "issue" with "dispute," many state summary judgment rules retain the "genuine issue" terminology. Compare FED. R. CIV. P. 56(a) ("The court shall grant summary judgment if the movant shows that there is no genuine dispute as to any material fact ...."), with, e.g., WYO. R. CIV. P. 56(c) ("The judgment sought shall be rendered if ... there is no genuine issue as to any material fact...."). 
courts in franchisor liability cases sometimes engage in questionable judicial fact finding. Some courts have made unconvincing assumptions and assessments about franchisor control that need to be considered more carefully and realistically. Moreover, mere clever labeling and drafting in documents should not preclude inquiry by counsel and courts into the fundamental issue of the reality of control in the franchisor-franchisee relationship. Where plaintiffs pursue apparent agency or estoppel claims, dismissing their cases because of premises signs, web site notices, or the like may be inappropriate in the face of the other manifestations to which they have been subjected. After all, customers patronizing franchised businesses lack the sophistication, time or information to negate the powerful impression made by franchisor publicity before they buy their sandwich or register at a hotel. Injured plaintiffs and franchisor defendants should expect realism and not generalized, arbitrary rules in the factual assessment of their positions. Nor is the exclusion of relevant evidence of franchisor manifestations, such as national advertising, appropriate. Obviously, respect for courts is undermined by improper fact finding.

Guidance by analogy or otherwise from agency or tort principles and the underlying policies they serve is reasonable in franchisor liability cases. As courts settle upon applicable legal doctrines for franchisor liability, a vitally important policy consideration is the extent to which tort responsibility will encourage franchisors to emphasize health and safety considerations that would prevent injuries, thereby benefiting individuals and society. 